\title{
5
}

\section{IMMIGRATION AND POPULISM IN THE NEW ZEALAND 2017 ELECTION}

Kate McMillan and Matthew Gibbons

By the end of the 2010s, anti-immigration populist parties held seats in 19 national parliaments across Europe (British Broadcasting Corporation, 2019). In Hungary and Poland, such parties led their respective governments; in Italy, Sweden and Slovenia, they had received the largest proportion of votes in recent national elections. Anti-immigration parties increased their representation in the European Parliament following elections in mid-2019, and, even as some far-right parties lost support in that election, more voters from the United Kingdom, France, Slovenia, Italy and Hungary supported their respective right-wing, anti-immigration populist parties-United Kingdom Independence Party, National Rally, the Slovenian Democratic Party, Lega and Fidesz-than other parties. Moreover, railing against immigration (and the multiculturalism to which it gives rise) was not the sole province of far-right populist parties in Europe; this approach had become core politics for mainstream centre-right leaders in major liberal democracies. Donald Trump, David Cameron, Nicolas Sarkozy and every Australian Liberal prime minister since and including John Howard had all deployed anti-immigration rhetoric for electoral gain. Thus, by 2020, a kind of populism described as 'exclusionary' by Mudde and Kaltwasser (2013) was firmly established in Western liberal democracies. In this kind of populism, a virtuous 'us'- 
'the people'-are defined in opposition not only to populism's traditional foe- the 'elites' - but also against immigrants, asylum seekers and ethnic and religious minorities.

The electoral success of populist anti-immigration parties has raised fears regarding a global trend away from liberal democracy and towards anti-pluralism, authoritarianism, nationalism and even fascism. In this chapter, and in line with the central theme of this book, we ask whether New Zealand is an exception to, or another example of, such a trend. We acknowledge, however, the need for a much clearer definition of this 'trend' we are examining. After all, not all parties advocating a reduction in immigration are populists and not all populists are 'exclusionary', nativistic, authoritarian or right-wing (Norris \& Inglehart, 2019). Therefore, our queries focus on whether New Zealand has experienced a phenomenon in which anti-immigration sentiment is both increasing and associated with support for populism of an 'exclusionary', authoritarian or nativistic variety.

Superficially, this inquiry might be dispensed with reasonably quicklysupport for New Zealand's populist anti-immigration party, New Zealand First, dropped between 2014 (9 per cent) and 2017 (7.2 per cent). Further, as Chapter 3 reports, the New Zealand Election Study (NZES) data do not demonstrate a particularly strong appetite for authoritarian populism among New Zealand voters. Combined, these statistics would suggest that, in 2017, New Zealand presented a clear exception to the phenomenon of growing support for anti-immigration exclusionary populism. Yet, almost half of NZES respondents in 2017 wanted immigration levels reduced, there was a significant increase in the proportion for whom immigration was the most important issue at the polls between 2014 and 2017, and just over 20 per cent thought immigration posed a threat to New Zealand's culture. Further, in the context of record immigration numbers in the year ahead of the election, both major parties (Labour and National) and the Green Party proposed significant cuts to immigration, breaking these three parties' support, since the early 1990s, for existing immigration policies. Then, post election, Labour entered into a coalition with New Zealand First, a party that had campaigned strongly for major reductions in immigration. These developments present a contradictory picture of New Zealand. Was it an exception only in terms of levels of support for immigration reduction and populism, or was it also an exception in terms of the relationship between immigration sentiment, populism and authoritarianism? 
Populism may, of course, take many different forms, including what Norris and Inglehart (2019) call 'authoritarian populism' (Golder, 2016; Mudde \& Kaltwasser, 2013). In their formulation, authoritarian populism is characterised by use of populist rhetoric to pursue values emphasising conformity and loyalty to, and security of, one's group and its leader, even at the expense of individual and minority rights. Given their emphasis on cultural conformity, those who support authoritarian values might see immigrants, particularly those who differ ethnically, culturally or racially from the native population, as challenging existing cultural and social norms. Therefore, authoritarian-populist parties frequently frame immigration as a danger to local culture, values and social norms (Norris \& Inglehart, 2019), resulting in the kind of exclusionary populism discussed earlier in this book. The research presented in Chapter 3 found that populism, authoritarianism, nativism, cultural conformity and opposition to immigration all form separate dimensions of public opinion in New Zealand.

Opposition to immigration may also be based on economic grounds, from those on both the left and right of the political spectrum. For example, those on the left who value economic equality may oppose immigration because, although immigration results in a larger economy, immigrants sometimes compete for jobs with less-skilled workers, whose real incomes are being eroded by automation and globalisation (Eatwell \& Goodwin, 2018). Further, immigration can place pressure on a country's public services and infrastructure and increase demand for housing (Sharpe, 2019). When housing prices increase, existing homeowners benefit; however, those renting in the public and private sector, including the children of existing homeowners, face higher housing costs. Although immigration usually has only a minor effect on wages and housing costs (Cochrane \& Poot, 2019; Edo, 2019), immigrants may be perceived as driving wages down and house prices up. Further, there sometimes exist incentives for left-wing parties to support the restriction of immigration, particularly when they face strong competition for working-class voters from an authoritarian populist party (Kosiara-Pedersen, 2019; Wagner $\&$ Meyer, 2016). Such parties may employ left-wing populist rhetoric to identify immigration as a threat posed by neoliberal business interests against the interests of both native and immigrant workers. By contrast, authoritarian populist parties may use exclusionary rhetoric to conflate what they identify as the cultural and economic threats posed by immigration. 
In this chapter, we examine the relationship between attitudes towards immigration, populism and other aspects of public opinion, using longitudinal data from the NZES. We focus on the demand side of electoral politics-that is, the extent to which voters display a desire for restrictive immigration policies, as measured by public opinion and voting behaviour over the past six elections in New Zealand. We also draw on comparative data, where available, from electoral studies in Australia, the United Kingdom, Ireland and the United States.

Our key finding is that the desire for reduced immigration in New Zealand in 2017 was more commonly a left-wing populist phenomenon than an authoritarian-populist phenomenon. This is not to say that exclusionary populist and authoritarian values were not present among some of those who desired the reduction of immigration. They were present, particularly among New Zealand First voters; however, our analysis shows that concern regarding inequality and support for redistribution and trade unions better explain restrictive immigration attitudes than do exclusionary populist or authoritarian views.

Given that context helps shape whether and how populism arises and succeeds (Golder, 2016; Lees-Marshment, 2009) and that the 'supply' of different types of populism can help create and shape latent demand and meet existing demand for such populism, we begin our discussion with a brief overview of New Zealand's contemporary immigration experience, its specific electoral settings and the supply side of the anti-immigrationpopulism equation in New Zealand ahead of the 2017 election.

\section{New Zealand's Immigration and Electoral Settings}

Immigration is core to the human experience in New Zealand. Voyagers from Eastern Polynesia first settled the landmass they called Aotearoa at the end of the 13th century (Wilson, 2005), developing over time the culture, language and traditions now known as Māori. European settlers began arriving in significant numbers from the mid-19th century and, by as early as 1858 , outnumbered Māori. Until the late 20th century, the population was overwhelmingly composed of the European or Pākehā majority, predominantly from the United Kingdom, and the Māori minority, now considered indigenous. Low numbers of migrants from 
China, India, the former Yugoslavia, the Netherlands, Denmark and Poland also settled in New Zealand from the mid-19th century, joined from the 1950s onwards by people from the Pacific Islands-Samoa, Tonga, Fiji, the Cook Islands, Niue and Tokelau-many of whom were recruited to work in New Zealand's expanding post-war manufacturing industries. In the 1970s, New Zealand accepted several thousand refugees from Vietnam, Laos and Cambodia. For much of the post-war period, however, New Zealand operated a restrictive immigration policy, strictly linking immigration opportunities to gaps in the labour market and exercising a statutory preference for migrants from 'traditional source countries', meaning, primarily, the United Kingdom and northern Europe.

A review of immigration policy in 1987 led to the removal of this 'traditional source country' preference. In 1991, the introduction of a points-system immigration policy paved the way for a new era of immigration into New Zealand. Since 1991, New Zealand has experienced large-scale flows of immigration from new sources, most notably China, India and the Philippines. By 2018, a little over 27 per cent of New Zealand's population was born overseas (Statistics New Zealand, 2019), one of the highest rates among OECD countries.

Nevertheless, immigration has generally been of low electoral salience for most New Zealanders, despite New Zealand First's repeated attempts to make it an election issue since the party's formation (McMillan, 2005). The low electoral salience of immigration may be explained by several factors, including the country's long history of migration and settlement; the domination of skilled migration since the early 1990s; very low levels of illegal or irregular migration; New Zealand's geographical isolation and, hence, low threat perception; low unemployment; a dominant media and political narrative that immigration is crucial to New Zealand's economy; and, for most of the time since 1987, a bipartisan agreement between the two major parties that immigration was both desirable and manageable. The free-movement agreement that New Zealand has with Australia is likewise comparatively uncontroversial, largely because many more New Zealanders take advantage of this arrangement to live in Australia than the reverse. Refugee policies have been similarly uncontroversial. Indeed, the most recent (2018) refugee-related campaign in New Zealand argued, successfully, that New Zealand ought to increase the number of refugees it should accept each year (Doing our bit, 2018). 
New Zealand's electoral settings also contribute to its immigration politics. Resident non-citizens have possessed national voting rights since the 1970s (Barker \& McMillan, 2014) and the proportional electoral system has facilitated the representation of ethnic and immigrant minorities (McMillan, 2019). The enfranchisement of rapidly growing immigrant and ethnic minority populations has caused all major parties to expend considerable energy on wooing the Chinese, Indian, Pasifika and Filipino votes; alienation of these groups has the potential to inflict considerable electoral cost.

New Zealand's media landscape is also important, which, while highly commercialised and concentrated, does not include any locally produced 24-hour cable news networks. Such networks (e.g. FOX in the United States and SKY in Australia) tend towards highly combative and polarising programming that deliberately amplifies conservative populist politicians' exclusionary messages. News Corporation, which created both of those networks, in addition to owning various conservative newspapers in Australia, the United Kingdom and the United States, no longer has a stake in the New Zealand media market. Talkback radio in New Zealand tends to be right wing; however, no host can claim the influence of their counterparts in Australia and the United States. The territorial monopoly enjoyed by all the metropolitan newspapers has caused these titles to strive for internal diversity in an attempt to reach the largest possible audience. Crucially, all major newspapers, in addition to the websites of mainstream commercial broadcasters, have signed the Media Council's Statement of Principles, which requires signatories to be bound by principles of fairness, balance and accuracy, and provide that 'in articles of controversy or disagreement, a fair voice ... be given to the opposition view' (New Zealand Media Council, 2020). Broadcast media are statutorily bound to fairness, balance and accuracy by the 1989 Broadcasting Act. Audiences from both sides of the political spectrum will inevitably see partisan bias in New Zealand's news coverage. However, detailed content analysis of the three major metropolitan newspapers (The NZ Herald, The Dominion Post and the Christchurch Press) and the two main television channels (TVONE and TV3), across three elections between 2008 and 2014, found no sustained bias towards for or against either of the two major parties (Bahador, Boyd \& Roff, 2016). 


\section{Immigration and Party Positioning on Immigration in 2017}

Net migration into New Zealand was at an all-time high during the year prior to the 2017 election, driven largely by New Zealanders returning from Australia following a downturn in the Australian economy but also by the number of people entering on temporary work visas (Statistics New Zealand, 2017). Net permanent and long-term migration had risen to 72,000 in June (1.2 per cent of New Zealand's total population of 4.5 million), 15 times the net migration of 4,700 when National had taken office nine years earlier (Barker, 2018).

Considerable media attention was given to this dramatic increase in migration (New Zealand Herald Business Desk, 2017; McKenzie, 2017; Rutherford, 2017; Tan, 2017). Media also reported on various forms of immigration fraud and immigrant exploitation. The high number of international student numbers in New Zealand's tertiary education sector, some of whom had been revealed to be on fraudulently acquired visas, also drew attention (Speedy \& Bryant, 2016). Other international students were reportedly enrolled in sham or low-quality, non-university courses, only to access a post-study work visa in New Zealand (Laxon, 2016). Stories of migrant labour exploitation, particularly among international students seeking to transition to permanent visas, also began to emerge with greater frequency (Dozens of employers under Immigration NZ investigation for alleged immigration fraud, 2017; Tupou, 2017). This reporting followed in the wake of claims by New Zealand's trade union movement that migrants were being employed in industries such as farming and hospitality for less than the minimum wage, thus reducing wages for New Zealand workers (Concern over migrant 'exploitation' in Queenstown, 2015; Towle, 2016).

Simultaneously, media discourse increasingly linked record immigration with other salient concerns, such as growing inequality, homelessness, the unaffordability of housing and pressure on the country's social and roading infrastructure (Barker, 2018). Housing costs had increased for all income quintiles and, by 2017, had more than doubled (since 1990) as a percentage of household income for the lowest income quintile (Perry, 2019, p. 72). Indeed, by 2017, high housing costs meant that, despite wage increases, the median discretionary household income in some of New Zealand's fastest growing cities, including Auckland, Hamilton and 
Tauranga, had fallen sharply over the previous few years (PWC, 2019). New Zealand now had the most unaffordable house prices in the world (Global House Prices, 2017). While the media and politicians also discussed other reasons for increased housing prices, such as restrictive planning laws and the absence of a capital gains tax (Schrader, 2018), the scene was set for immigration to become a major election issue.

Five months ahead of the September election, the National-led government proposed several changes to immigration policy: raising the salary cap needed for an applicant to qualify under the skilled migrant category, a three-year visa limit for lower-skilled workers and more restrictive rules for partners and children of migrants. These changes were marketed with the tagline 'Kiwis first' (McBeth, 2017) and were announced the day after the Australian Government declared it was 'putting Australians first' with changes to its visa system (specifically, 457 visas) (Kimmorley, 2017). In the context of Trump's pronouncement of an 'America First' foreign policy, this framing had clear populist resonances for those who wished to see them. However, following significant backlash from employer groups and farmers, National retreated on the more restrictive aspects of the proposals (Davison, 2017). The watered-down policy changes did more to restrict migrants' access to permanent status than reduce the number of people entering New Zealand (Collins, 2017). By the time the election campaign began, National was no longer discussing the need to decrease immigration. Rather, discussion of immigration policy was embedded within its broader narrative about wanting to keep New Zealand 'open', particularly for business (see e.g. Woodhouse, 2017).

National had governed during the previous term with support from three other parliamentary parties: the libertarian ACT Party, the Mãori Party and centrist United Future. None of these parties proposed any restrictions on immigration ahead of the 2017 election. Indeed, ACT, United Future and the Māori Party competed on openness to immigration (Jones, 2017; Maori Party, 2017).

In contrast, Labour entered the election promising to 'take a breather' on immigration (New Zealand Labour Party, 2017), aiming to cut immigration by 20,000-30,000 people per year. This was to be achieved by removing work rights for international students not studying a university-level course and by 'making sure that work visas are not being abused to fill low-skill, low-paid jobs' (New Zealand Labour Party, 2017). It was these policy goals, developed in response to concerns regarding 
migrant and local labour exploitation and highlighted by Labour's traditional trade union base, that led some commentators to accuse Labour of 'choosing to play the anti-immigration card' (Campbell, 2017). The Wall Street Journal even compared Labour's leader, Jacinda Ardern, to Donald Trump on immigration (Pasley, 2017). Ardern vociferously rejected such comparisons (Burr \& Gower, 2017) and Labour assiduously attempted to demonstrate that they were not anti-immigration. Their proposed policy changes were introduced with the statement that 'New Zealand is a country built on immigration. Migrants bring to New Zealand the skills we require to grow our economy and vibrant cultures that enrich our society' (New Zealand Labour Party, 2017), a refrain that prefaced all its speeches or public statements concerning immigration policy changes (McMillan, 2017b). Labour repeatedly attempted to emphasise its policies' continuity with New Zealand's post-1991 openness to immigration and the value that immigrants brought to the country, while simultaneously identifying the negative effects on housing, social services and infrastructure of existing levels and types of immigration:

We have always welcomed migrants to our country and will continue to do so. But, in recent years, our population has been growing rapidly as record numbers of migrants arrive here ... Labour will invest in housing, infrastructure, public services and in training New Zealanders to fill skills shortages. At the same time, we will take a breather on immigration. We will do this by making sure that work visas are not being abused to fill low-skill, low-paid jobs, while ensuring that businesses can get the skilled workers they need. (Labour Party of New Zealand, 2017)

In their speeches and press releases in the months leading up to the election, Labour avoided mentioning difficulties with immigrant acculturation, or employing other ethnically or religiously focused frames that might be understood as culturally exclusionary, at least according to the news reports of their speeches, campaign events and website (McMillan, 2017a). Regarding the immigration debate during the campaign, Deputy Labour Leader Grant Robertson said that 'Anyone who makes it about immigrants, or indeed about their race ... must be called out for what they are doing as being wrong and against the values of Labour and of New Zealanders' (Edwards, 2017). This did not stop commentators in New Zealand accusing Labour of dog-whistling on immigration (Edwards, 2017; Jayasinghe \& Ratnayake, 2017; Spoonley, 2017). These accusations were often made with reference to Labour's disastrous attempt 
in 2015 (under a different leader) to highlight the issue of foreign buyers speculating in the New Zealand housing market by identifying how many of those buyers had 'Chinese-sounding names' (McCrow-Young, 2017; Rutherford, 2015).

The Green Party was similarly concerned about the potential for their immigration policy to be perceived as xenophobic, in the context of antiimmigration politics internationally. In 2016, the party had suggested that New Zealand limit immigration so that population growth stayed within 1 per cent, citing concerns regarding New Zealand's capacity to grow more quickly than this. However, during the 2017 election campaign, Green co-leader James Shaw apologised to ethnic communities for his earlier comments, saying:

Because the background terms of the debate are now so dominated by anti-immigrant rhetoric, when I dived into numbers and data, a lot of people interpreted that as pandering to the rhetoric, rather than trying to elevate the debate and pull it in a different direction. We were mortified by that because, in fact, the Greens have the ambition of being the most migrant-friendly party in parliament. And I am sorry for any effect it may have had on your communities. (James Shaw 'sorry' after immigration policy slammed as racist, 2017)

With Labour's proposals to cut immigration, New Zealand First no longer had sole ownership of the anti-immigration space. It continued, however, to distinguish itself from the other parliamentary parties' approach to immigration by its leader's willingness to criticise immigration and asylum policies on ethnic, religious and cultural grounds. Winston Peters' speech on 6 June 2017, given in parliament to mark terror attacks in London the previous week, was illustrative of the party's positioning on immigration vis-à-vis the other parties. In this speech, Peters suggested that the families of those who carried out the attacks would have known of the terrorists' intentions and kept silent. 'What is happening', he said:

[Is] that families, friends, and confidants are choosing to turn the other cheek, choosing silence, rather than turn these monsters in. That may be the culture of Damascus, but it is not ours. It may be acceptable in Tripoli, but it most certainly is not acceptable in New Zealand. While the Islamic community must clean house by turning these monsters in, it starts with their own families. (2017) 
The lesson for New Zealand, he argued, must be that:

[It] avoid the same politically correct trap that has allowed such communities apart to form-that is, it is we who must change as a society, they say, to accommodate the cultural practices and traditions of others; that, in some twisted spirit of inclusiveness, it is we who must change, and not them. No longer. We must stop the slide-as a people, as a culture in the West, as people who believe in freedom and liberty, and, indeed, as a country - before we see in this country, in a New Zealand locality, a repeat of these events. (2017)

These comments are consistent with other comments Peters had made over the years (see e.g. Peters, 2005). Speeches made by the other parliamentary parties following the attacks, by contrast, emphasised unity and solidarity. National's Deputy Leader Paula Bennett condemned the attack, saying 'we stand united with London'. ${ }^{1}$ The Labour Party's finance spokesperson, Grant Robertson, explicitly evoked solidarity with Muslim communities, saying:

We should also show our support to the Muslim community here in New Zealand, who are as appalled and disgusted by the actions of these terrorists as anyone else. We can defeat these extremists through our unity, our acceptance of diversity, and our resolve to not allow hatred and intolerance to grow.

United Future's Peter Dunne also referenced the New Zealand Muslim community, who had, he said, come together the previous week to celebrate Ramadan 'in peace and goodwill and tolerance and openness'. We needed, he said, 'to be working with people of like mind to achieve positive outcomes, not simply fuelling the fires of bigotry'. Marama Fox, co-leader of the Māori Party, said 'the terrorists and extremists who perpetuated this despicable act seek to drive a wedge between communities, but they will not succeed, and now, like many times before in its history, London stands united against a threat'. James Shaw, co-leader of the Green Party, recalled earlier terrorist attacks in London, each of which he said had attempted to drive particular minority communities 'into the ocean', offering, instead, solidarity: 'To the mayor, Sadiq Khan, and to the people of London, we want to say: we are with you. Kia kaha (Be strong)'. ACT's David Seymour, perhaps more ambiguously, called out Peters'

1 All quotes responding to the Christchurch massacre are from New Zealand Government [Hansard] (2017), unless otherwise noted. 
response as 'naked political opportunism', while also identifying a need for a 'wider and more serious debate about when and whether such an event can happen here ... without naivety' (New Zealand Government [Hansard], 2017).

To summarise, in the year preceding the election, the four largest parliamentary parties-National, Labour, the Greens and New Zealand First-all proposed some restrictions on immigration. This presented a significant change from the historical bipartisan pro-immigration position held by both National and Labour. National demonstrated some willingness to engage in exclusionary populist language with its later-abandoned 'Kiwi-first' language; however, Labour and the Greens were anxious not to be seen as stirring the anti-immigration pot with exclusionary rhetoric, even as they proposed significant reductions to immigration. A clear distinction between rhetoric and policy is, of course, very difficult to maintain - a political party that identifies any aspect of immigration as problematic may be interpreted as being 'antiimmigration' or even 'anti-immigrant'. Aware of this, both Labour and the Green Party took pains to pre-empt such accusations by repeatedly stating their strong support for both immigration and immigrants, in addition to both explaining and criticising 'dog-whistle'-type anti-immigration tactics. Arguably (some alternative interpretations are reported below), the Labour Party's proposals for immigration restrictions may be read as a form of socio-economic populism (Kyle \& Gultchin, 2018), in that they responded to public concerns regarding the labour market, economic and infrastructural consequences of immigration, while rejecting a cultural or 'exclusionary' form of populism (Golder, 2016; Mudde \& Kaltwasser, 2013).

\section{Data and Concepts}

We used time series data from the NZES, between 2002 and 2017, using data collected after each three-yearly election. In 2017, the data were compiled from a random sample of 3,455 people on the New Zealand electoral roll. Surveys were posted to randomly selected, registered electors across New Zealand, immediately following each election. Questions focus on voting choices, political opinions and the social and demographic characteristics of respondents. New Zealand's indigenous 
Māori population and young voters are usually oversampled, to ensure that the sample better matches New Zealand's population. Further, the data are weighted by gender, age, Māori ethnicity and how and whether people voted. NZES data are available for analysis and can be downloaded from the NZES webpage (www.nzes.org/exec/show/data).

Where available, comparative data from national election studies in the United Kingdom, United States, Australia and Ireland were used. We also used data from Module 5 of the Comparative Study of Electoral Systems (CSES), which focuses on measurements of populism. The NZES is involved in the CSES, which ensures some New Zealand questions on migration are the same as those asked in other countries.

\section{New Zealanders' Attitudes towards Immigration}

Various previous studies have examined New Zealanders' attitudes towards immigration and immigrants (Ipsos, 2018; Ward et al., 2011). Some have mapped New Zealanders' attitudes towards immigration to their electoral behaviour. For example, Vowles, Coffé and Curtin (2017) used NZES data to examine attitudes to immigration by party support in 2014, as did Crothers (2014) for the 2011 and 2014 general election, and Donovan and Redlawsk (2018) for the 1996 general election. Further, there exist numerous comparative studies of 'radical right-wing', 'right-wing' populism and generic populism, which include discussion of Winston Peters and the party he established and has led since 1993-New Zealand First (Betz, 2002; Betz \& Johnson, 2004; DeAngelis, 1998; Denemark \& Bowler, 2002; MacDonald, 2019; Moffit, 2017). We build on the work of Vowles et al. and Crothers to examine attitudes towards immigration and how this translated into voting behaviour in the 2017 New Zealand general election campaign.

We are particularly interested in whether New Zealand is becoming more opposed to immigration and if views on immigration and populism are connected. Our first query concerns New Zealanders' support for current levels of immigration over the past 15 years and how this compares to support in other Anglo-democracies. Figure 5.1 shows the percentage of people in New Zealand, Australia and the United Kingdom who think 
immigration should be reduced a little or a lot. In 2017, 48 per cent of New Zealanders wanted to see immigration into the country reduced either 'a lot' or 'a little'. This figure was up slightly, but not significantly, from 2014 (46 per cent) and 2011 (45 per cent), but down from 2008 (50 per cent). The statistically significant increase occurred between 2002 (35 per cent) and 2005 (46 per cent). New Zealanders' stable attitudes towards immigration over the 12 years between 2005 and 2017 is particularly notable in light of the 15-fold increase in net migration since 2008. Attitudes to levels of immigration in New Zealand were not dissimilar to those in Australia, where the desire to see migration reduced grew between 2004 and 2010, before falling between 2010 and 2013 . A lower percentage of Australians ( 41 per cent) wanted to see immigration reduced in 2016 than did New Zealanders in 2017. Public opinion in the United Kingdom, by contrast, has been consistently in favour of reducing immigration, with 77-79 per cent wanting a reduction between 2003 and 2011, although that figure dropped to 69 per cent in 2015.

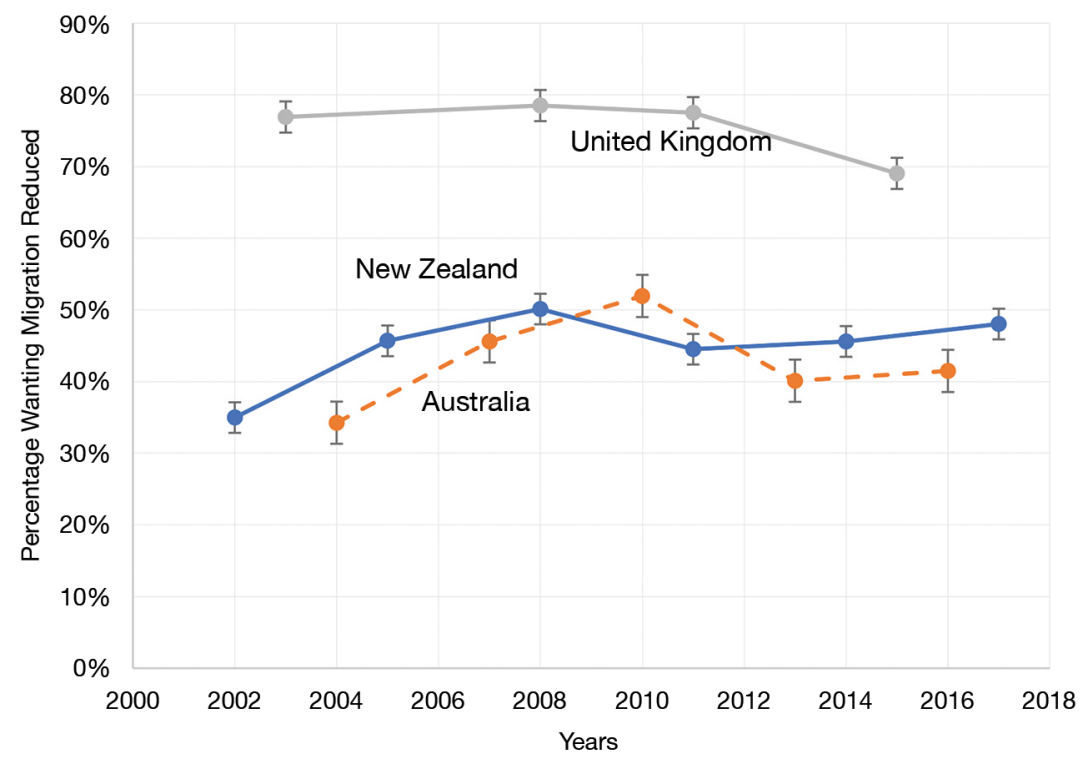

Figure 5.1: Percentage of people who want immigration reduced 'a lot' or 'a little' in New Zealand, Australia and the United Kingdom.

Source: Comparative Study of Electoral Systems (2019); New Zealand Election Study (2017). 
The significance of levels of support for immigration is mediated by how important people consider the issue to be. Bartle et al. (2020) found believing immigration to be the most important issue facing their country was a significant indicator of support for authoritarian forms of populist attitudes in nine of 10 European countries (Bartle et al., 2020, p. 57). Thus, our second query concerns the salience of immigration over time in New Zealand and elsewhere, measured by responses to an open-ended question regarding the most important issue facing the country. Here, we see a significant change between 2014 and 2017 in New Zealand, with approximately 6 per cent of NZES respondents mentioning immigration or migration as part of their reply to this question, up from 1 per cent in 2014. The only time immigration has been of similar importance during the period covered was in 2005, when almost 4 per cent of respondents mentioned immigration or migration as part of their answer to the most important problem. However, even in 2017, immigration was much less important to voters than the economy, housing, health and inequality (see Chapter 2, Figure 2.2). The percentage of New Zealanders who thought immigration was the most important issue in 2017 was similar to that in Canada ( 2 per cent in 2015) and Australia in 2019, when 3 per cent of respondents to the Australian Election Study ranked immigration as their most important issue, although this rose to 6 per cent when combined with 'refugee and asylum-seekers' (Cameron \& McAllister, 2019). Immigration was clearly a much less salient issue in either New Zealand or Australia than it was in the United Kingdom, where up to 40 per cent of voters rated it the most important issue in 2015 (Ipsos Mori, 2020). Immigration has increased in salience in the United States since the early 2010s and has become more important since Trump became President, with 23 per cent naming it their most important issue in 2019 (Jones, 2019).

Thus far, our analysis has shown that New Zealanders were less opposed to immigration than those in the United Kingdom and much less likely to think it was a highly important issue. We now investigate, in more detail, attitudes towards immigration: did people think it was good or bad for the economy, did they worry that it had harmful cultural effects (Malhotra, Margalit \& Mo, 2013; Markaki \& Longhi, 2013) and did they think immigration increased crime rates? 


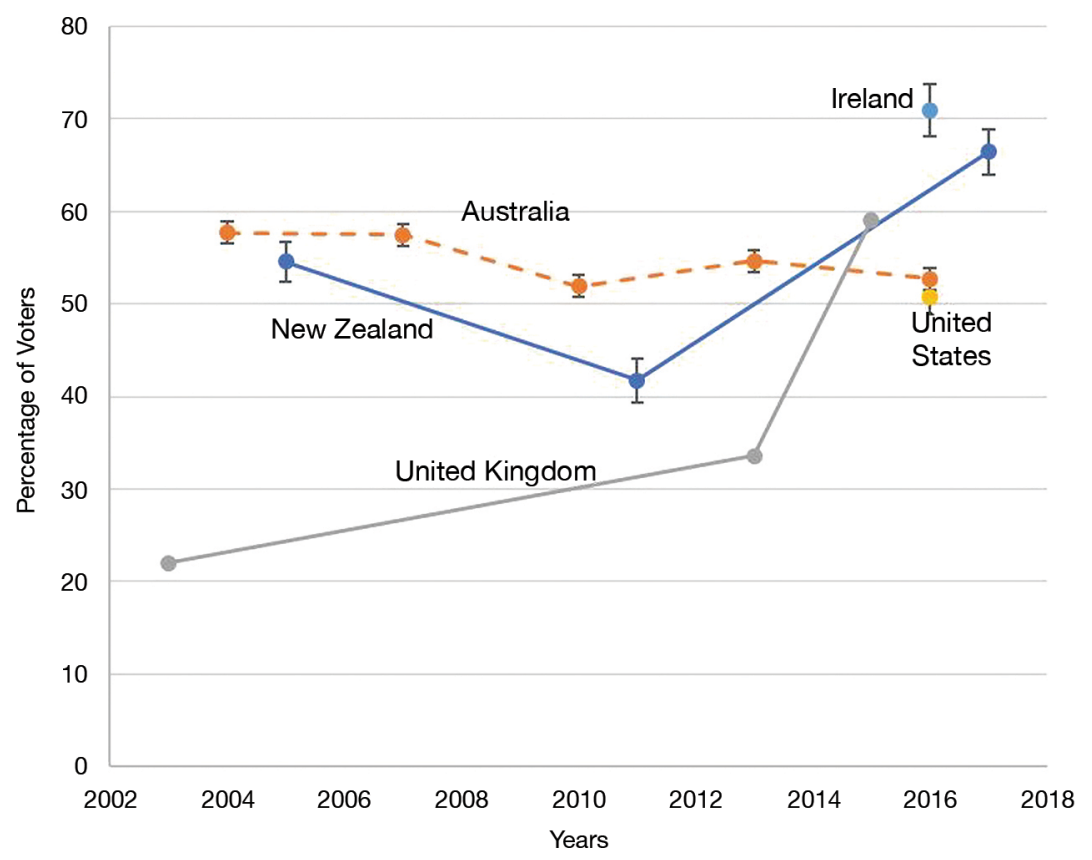

Figure 5.2: Percentage of voters who agree or strongly agree that immigration is good for the economy.

Source: Comparative Study of Electoral Systems (2019); New Zealand Election Study (2017).

Figure 5.2 shows that 66 per cent of New Zealanders in 2017 either agreed, or strongly agreed, with the statement that immigration is good for the economy'. This figure was up from both 2011 ( 42 per cent) and 2005 (55 per cent). The 2017 result for New Zealand overlaps with the confidence intervals for Ireland, where 71 per cent of people in 2016 thought migration was good for the economy. The majority of people in Australia, the United States and the United Kingdom also considered immigration to be good for the economy in recent elections; however, New Zealanders were significantly more likely to think this is the case than voters in those countries.

Views on whether migration is good for the economy are a strong predictor of the level of support people have for existing levels of migration (see Figure 5.3). Only approximately 21 per cent of the 16 per cent of New Zealanders who (in 2017) strongly agreed that migration was good for the economy were in favour of reducing migration 'a little' or 'a lot'. Indeed, people who strongly agreed that immigration is good for the economy were the only group who wanted immigration increased. 
However, the 51 per cent of New Zealanders who simply agreed that migration had economic benefits and the 18 per cent of New Zealanders who were neutral or did not know were more than twice as likely to want migration reduced as those who strongly agreed that there are economic benefits. Even for the neutral group, the point estimate of 48 per cent meant than less than half of this group wanted migration reduced. In contrast, of the 12 per cent of New Zealanders who disagreed that migration had economic benefits, 83 per cent wanted migration reduced. Similarly, of the 3 per cent who strongly disagreed that migration had economic benefits, 89 per cent wanted migration reduced.

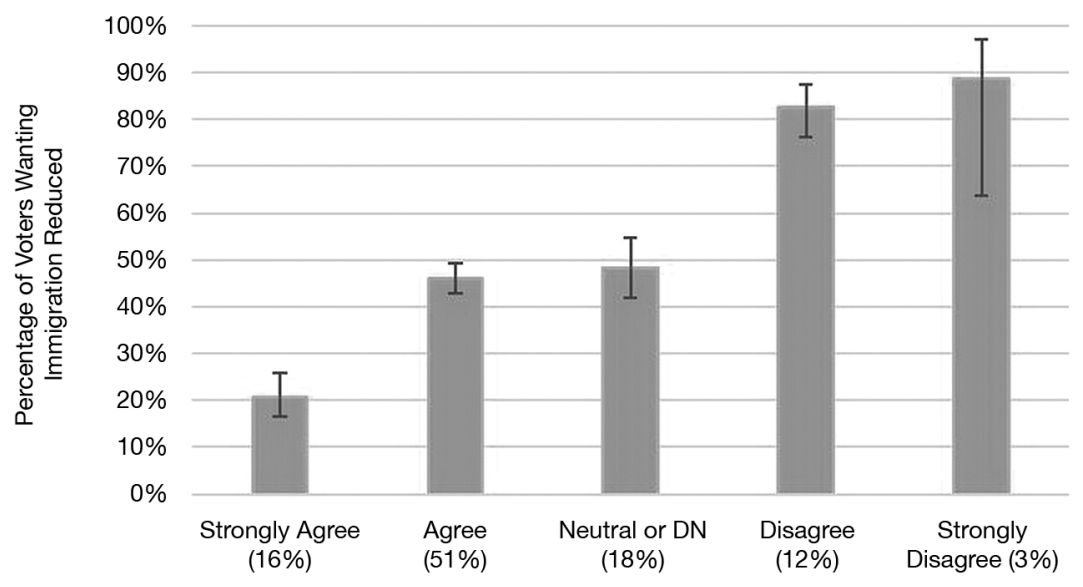

Views on Economic Benefits (Percentage of Voters in Brackets)

Figure 5.3: Percentage wanting immigration reduced by views on economic benefits.

Source: New Zealand Election Study (2017).

Our second, more detailed query, regarding attitudes towards immigration, asks whether people see immigration as a threat to culture. In 2017, when people were asked whether New Zealand culture is generally harmed by immigration, 5 per cent strongly agreed, 17 per cent agreed, 19 per cent were neutral or did not know, 34 per cent disagreed and 25 per cent strongly disagreed. People were less likely to think immigrants harmed New Zealand culture in 2017 than in 2011, 2008 or 2005 (see Figure 5.4). The percentage who saw migrants as a cultural threat was very similar to the percentage in Ireland and the United States. Equivalent questions have not been asked in Australia and in the United Kingdom. 


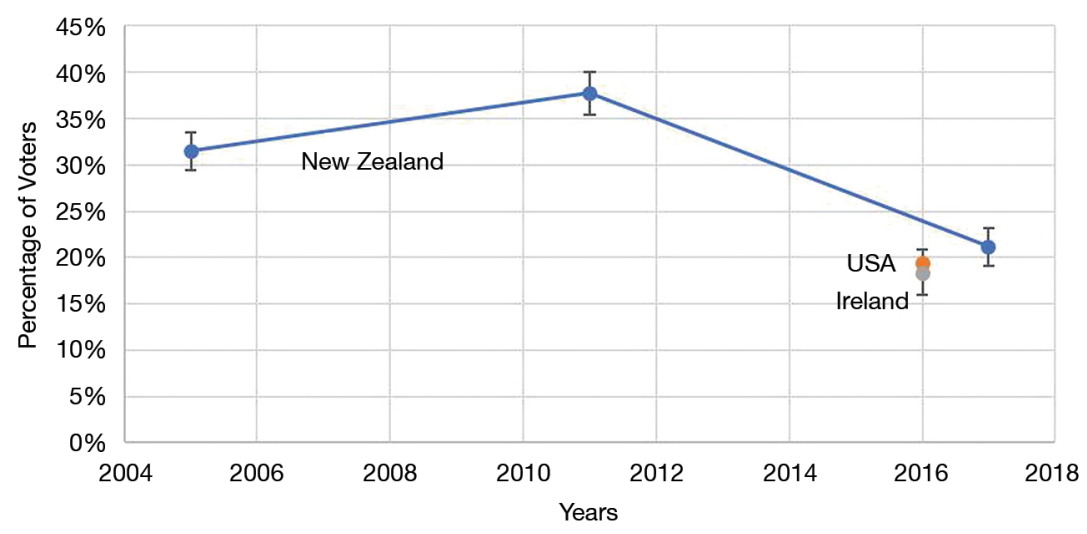

Figure 5.4: Percentage of voters who agree or strongly agree that migration is a threat to their country's culture.

Source: Comparative Study of Electoral Systems (2019); New Zealand Election Study (2017).

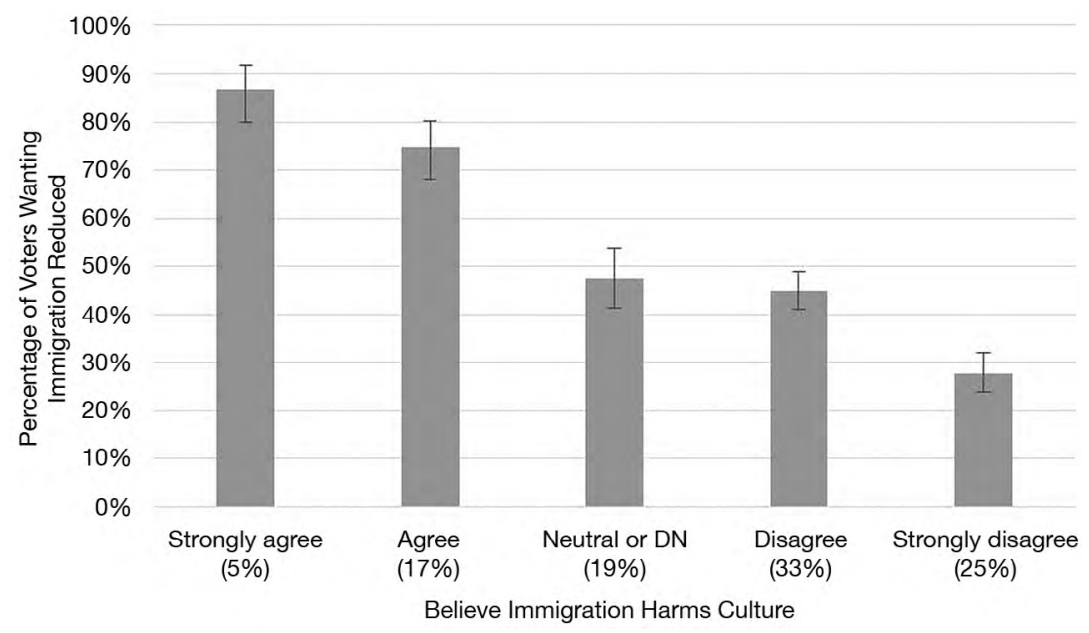

Figure 5.5: Percentage wanting immigration reduced by views on whether immigration harms culture.

Source: New Zealand Election Study (2017).

Unsurprisingly, New Zealanders who saw immigration as having negative cultural effects were those most strongly against increased immigration in 2017. Indeed, 87 per cent of the 5 per cent of New Zealanders who strongly agreed immigration had negative cultural effects wanted immigration reduced, while 75 per cent of the 17 per cent who agreed wanted immigration reduced (see Figure 5.5). Those who were neutral or disagreed that immigration had negative cultural consequences were 
relatively evenly divided on whether immigration should be reduced. In contrast, of the quarter of New Zealanders who strongly disagreed that migration had negative cultural effects, only 28 per cent wanted immigration reduced.

New Zealanders (15 per cent) were also much less likely than voters in the United States (28 per cent), Australia (33 per cent) and the United Kingdom (36 per cent) to think that immigrants increase crime (see Figure 5.6).

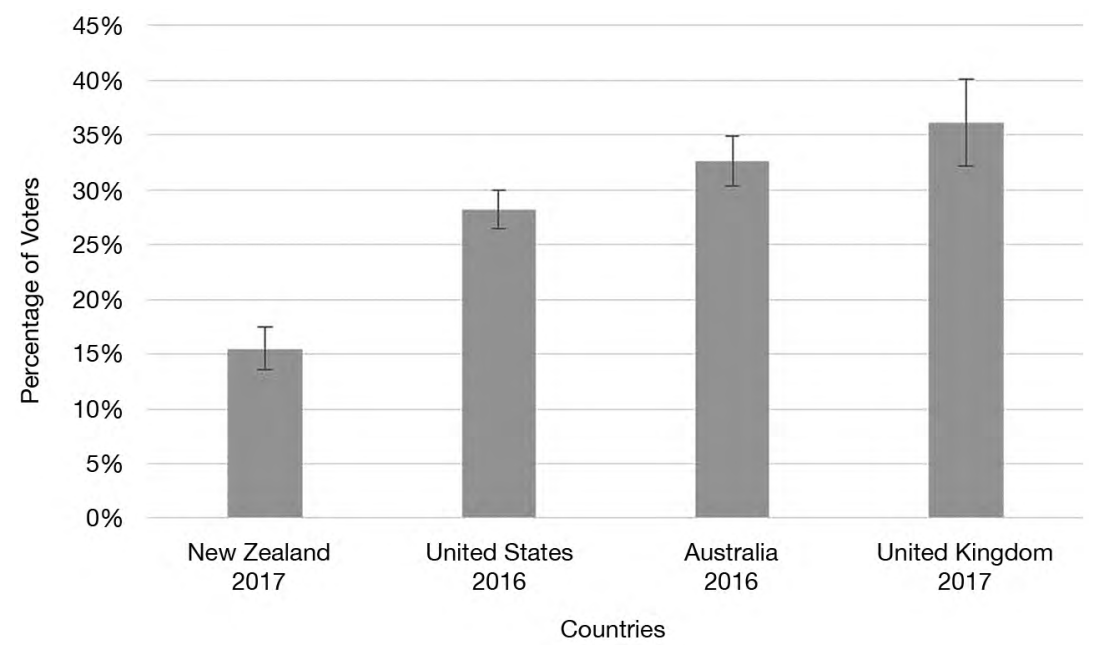

Figure 5.6: Percentage of voters who think immigrants increase crime rates.

Source: Comparative Study of Electoral Systems (2019); New Zealand Election Study (2017).

The data above provide some support for an 'exceptionalist' hypothesis; although just under half of New Zealanders wanted immigration reduced, this proportion had not increased significantly since 2005, even in the face of enormous increases in migration. Immigration had become more salient to New Zealanders, but only for a very low proportion of people, and was much, much less likely to be considered the most important issue than it was in the United Kingdom or the United States. In 2017, New Zealanders were also less likely to perceive immigrants as a threat to the economy or to law and order than people in Australia, the United Kingdom and the United States (at the time of their most recent elections). This suggests that New Zealand differs from each of these countries in terms of the demand for anti-immigration populism exhibited by its voters. 
The next section seeks to understand whether the quality of antiimmigration sentiment is similar to that found in our comparator countries. Here, we are interested in whether the same kinds of variables help to explain New Zealanders' feelings regarding immigration as have been found to explain them elsewhere. We are also interested in how views regarding immigration interact with populism, authoritarianism and other aspects of public opinion. Using the measures of public opinion developed by Greaves and Vowles (see Chapter 3), we attempt to tease out opposition to current levels of immigration in New Zealand influenced by populist values (defined here by support for views that position 'the people' as the legitimate source of power, in contrast to 'elites') from those influenced by authoritarian values (defined by 'prioritising group cohesion and seeking collective security over individual and minority rights and freedoms') or nativism (understood here as 'in-group exclusivity') (Greaves $\&$ Vowles; see Chapter 3). Further, we investigate how views on left-right economic policy and trade unions affect attitudes towards immigration.

\section{Attitudes towards Migration and Demographic and Educational Characteristics}

Consistent with findings elsewhere (Card, Dustmann \& Preston, 2005; Vowles et al., 2017), our analysis suggests that ethnicity, education levels, age, gender and income influence attitudes to immigration. To better understand the significance of each of these demographic factors, we used logistic regression (see Table A5.1) to test the relationship between support for reducing immigration (operationalised as indicating that immigration should be reduced a little or a lot); thinking immigrants are good for the economy, bad for New Zealand culture and cause crime (strongly agree, or slightly, for the latter three); and background characteristics. The background characteristics explain more of the variance in individual beliefs than for wanting to reduce immigration; however, all the results explain relatively little variance. Māori ethnicity was statistically significantly associated with wanting immigration reduced and thinking immigration was bad for New Zealand culture. The age and age squared variables were usually significant and work in opposite directions. The youngest voters are most in favour of immigration; opposition to immigration then increases with age, but at a decreasing rate. This also occurs in other countries and may reflect unmeasured cultural effects or perhaps older voters realising that, by increasing the size of the tax base, immigration 
improves the sustainability of New Zealand's universal superannuation scheme (O’Rourke \& Sinnott, 2006, p. 850). Women were less likely to think immigration was bad for New Zealand culture or caused crime.

Those with a university degree were more positive regarding immigration, which frequently reflected cultural values and beliefs associated with higher education (Hainmueller \& Hiscox, 2007, p. 399). People who believed they had good future economic prospects were more likely to think that immigration benefited the economy and to disagree with the idea that it threatened New Zealand culture. Despite rural areas economically benefiting from an inflow of farm workers, urban people were more likely to see immigration as having economic benefits. Those in public housing or living with relatives were less likely than other New Zealanders to believe immigration had economic benefits. National had reduced and more tightly targeted state housing entitlements while in government and people living in public housing may believe that immigrants, and particularly refugees, increase competition for public housing. Being part of a family that rented was associated with wanting immigration reduced, albeit at a 10 per cent level of statistical significance. For many in this group, achieving home ownership is an elusive goal and the 'perfect storm' of low outward immigration and high inward immigration between 2014 and 2017 had increased their housing costs (Cochrane \& Poot, 2019, p. 16).

\section{Attitudes towards Migration and Beliefs and Values}

We now test the effects of populism and authoritarianism on wanting immigration reduced by adding control variables. By doing so, and as displayed in Figures 5.7 and 5.8, we find that neither populism nor authoritarianism have direct effects on immigration preferences. The effects of populism are channelled through 'immigration prejudice' (based on the three questions regarding effects on crime, culture and the economy) and socio-economic attitudes (principally, support for unions and income redistribution). By contrast, the effects of authoritarianism are channelled through immigration prejudice alone. Therefore, in Model 1, without controls, populism, authoritarianism and efficacy are all associated with wanting immigration reduced (see Table A5.2). The effects of populism on views regarding immigration are clearly not just a reflection of low efficacy, which is operationalised in terms of believing that voting and 
who is in power makes a difference. With controls for views on the effects of immigration on the economy, culture and crime, only populism and efficacy remain statistically significant in explaining opposition to immigration (Model 2). As Table A5.2 and Figures 5.7 and 5.8 show, the effects of populism have been more than halved, while the effects of authoritarianism are now a small fraction of their previous size, although the coefficient for efficacy has increased in size. Views regarding the effects of migrants on crime, culture and the economy more directly measure prejudice against immigrants than populism and authoritarianism.
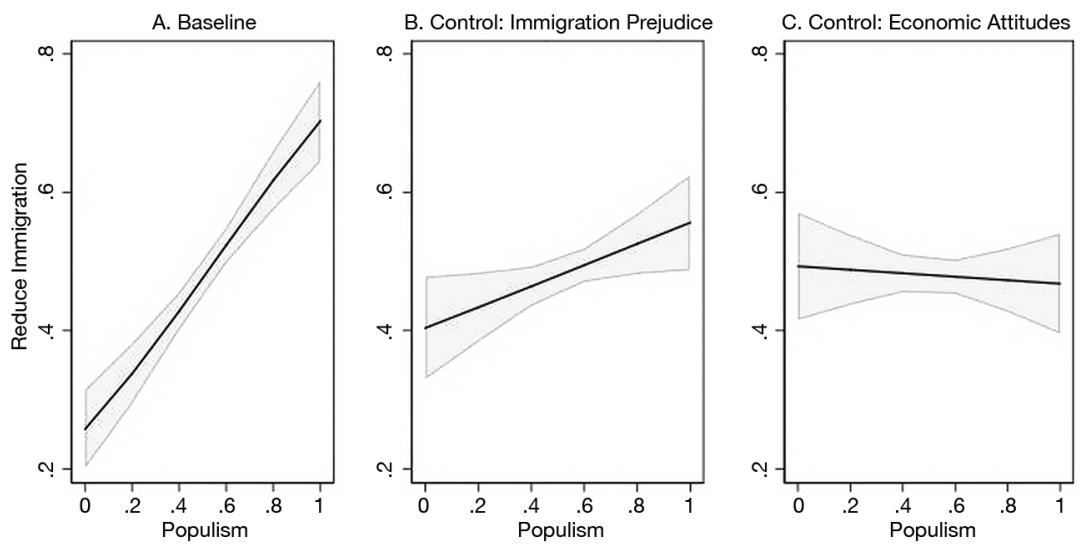

Figure 5.7: Decomposing the effects of populist attitudes on preference to reduce immigration.

Source: New Zealand Election Study (2017).
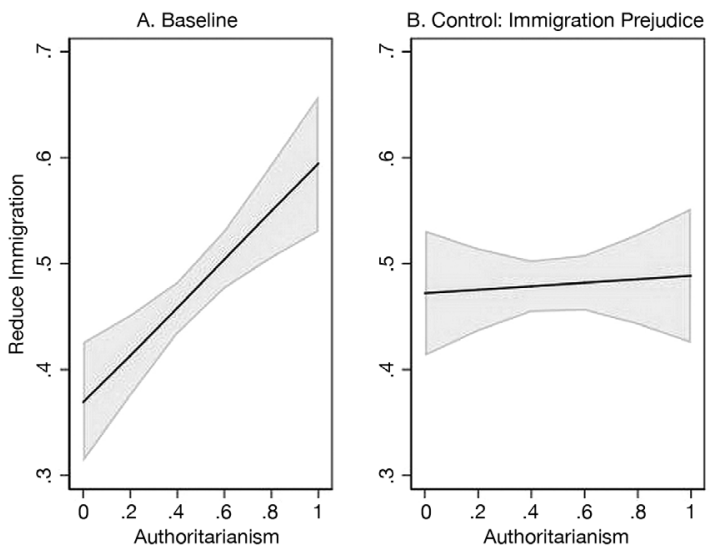

Figure 5.8: Decomposing the effects of authoritarian attitudes on preferences to reduce immigration.

Source: New Zealand Election Study (2017). 
Adding variables for cultural conformity and nativism views reduces the size of the efficacy coefficient; however, the effects on the populism coefficient are minimal (see Table A5.2, Model 3). Cultural conformity has been constructed from variables for the importance of language and customs to being a New Zealander and is statistically significantly associated with wanting immigration reduced. Nativist views have been constructed from variables for the importance of being born in New Zealand, having grandparents born in New Zealand and Māori ancestry (see Chapter 3). Although nativist views are associated with wanting immigration reduced, the coefficient is small and not statistically significant when variables for specific views on immigration are included. When the variables for specific views on immigration were dropped (results not included here), the coefficient for nativism was larger and statistically significant.

With variables for views on union membership and economic inequality (see Table A5.2, Model 4), the effects of populism become negative; however, Figure 5.7 shows that the effects are no longer statistically significant. Authoritarianism is more strongly associated with wanting immigration reduced than in Models 2 and 3, but the effects are not statistically significant in Model 5 when cultural conformity and nativism are added back to the model (see Table A5.2). Conversely, efficacy, views on specific aspects of immigration, cultural conformity and left-wing views on union membership and inequality are all statistically significant predictors of wanting immigration reduced (see Figure 5.9). Indeed, opposition to immigration is better explained by specific views on immigration and left-wing economic views than by populist or authoritarian views. High immigration has been perceived by New Zealand's trade union movement as detrimental to the interests of workers, and voters who support trade unions tend to share this view. Similarly, reducing immigration seems to be perceived by some voters as another way of reducing income inequality in New Zealand. Those who want more public housing favour less immigration, probably because larger immigrant populations increase pressure on the state housing stock; however, the coefficient is not statistically significant. Other economic variables tried included opposing the Trans-Pacific Partnership Agreement, which garnered significant opposition among voters in New Zealand between the 2014 and 2017 elections (Thousands turn out to protest TPP, 2015). 


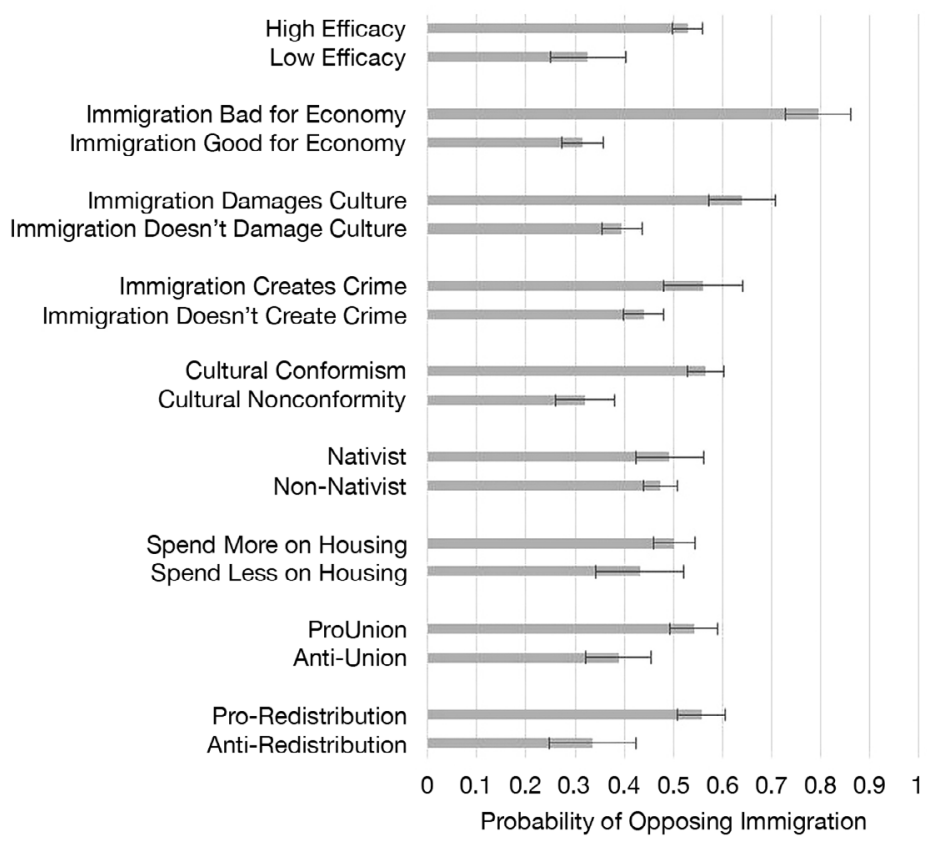

Figure 5.9: Probabilities of wanting migration reduced.

Source: New Zealand Election Study (2017) (see Table A5.2 [Model 5]).

Our findings in this section provide evidence both for and against the hypothesis that New Zealand is an exception to a trend towards exclusionary populist anti-immigration politics. Individual characteristics associated with wanting immigration reduced resemble those found in other research: being male, less educated, worried about future economic status and occupying rental housing all correlate with being more likely to want immigration reduced. However, the connection between wanting immigration reduced and populism or authoritarianism in New Zealand is weak; opposition to immigration tends to be driven by specific concerns regarding the economic, cultural and law and order effects of immigration (although, as we have seen, while the effects of these are strong, the number that think immigration is harmful is comparatively low). Opposition to current levels of immigration is also significantly related to concerns regarding inequality and support for organised labour, suggesting that wanting immigration reduced is sometimes more of a left-wing than a right-wing phenomenon in New Zealand. Notably, however, cultural conformism remains a significant predictor of wanting immigration reduced, as does political efficacy, both of which suggest some potential demand for culturally exclusionary forms of populism. 


\section{Party Support and Attitudes towards Immigration}

Having examined some of the factors influencing voters' attitudes to immigration, we now turn to the question of how these attitudes relate to partisanship. In 2017, voters for the populist New Zealand First Party showed the strongest support for reducing migration (see Figure 5.10), with 84 per cent of its voters wanting immigration reduced a little or a lot. The 95 per cent confidence intervals for New Zealand First do not overlap with those for any other party. Voters for the Green Party were least likely to want immigration reduced, with just 35 per cent of its voters favouring a reduction. Although the point estimate for National was lower than for Labour, the difference was minor and the confidence intervals overlap.

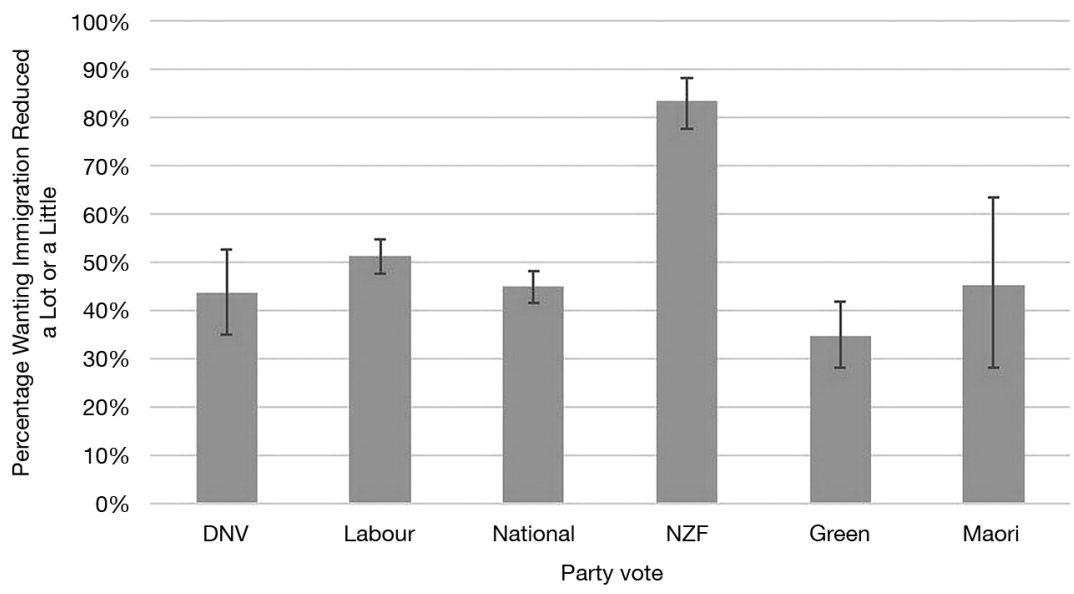

Figure 5.10: Percentage of voters wanting immigration reduced in 2017 , by party vote.

Source: New Zealand Election Study (2017).

The results of other elections (see Figure 5.11) show that New Zealand First voters have shown consistently high support for wanting migration reduced a lot or a little. This has distinguished them from Labour Party and National Party voters, with the confidence intervals for New Zealand First voters never overlapping those for Labour and National voters. The point estimate for wanting migration reduced seems to have gradually increased for Labour voters over time, whereas it has trended downwards for National voters. However, the results for the two parties are similar. In addition to changes in the saliency of migration, shifts in party support mean that, at some elections shown here, parties have attracted different types of voters. Voters for the environmentalist Green Party have always 
been least in favour of reducing immigration. Those who have voted for the neoliberal ACT Party, which, due to falling support, are not included in the graphs, have also expressed low support for reducing immigration. Non-voters (also not shown) have, by contrast, sometimes wanted immigration reduced.

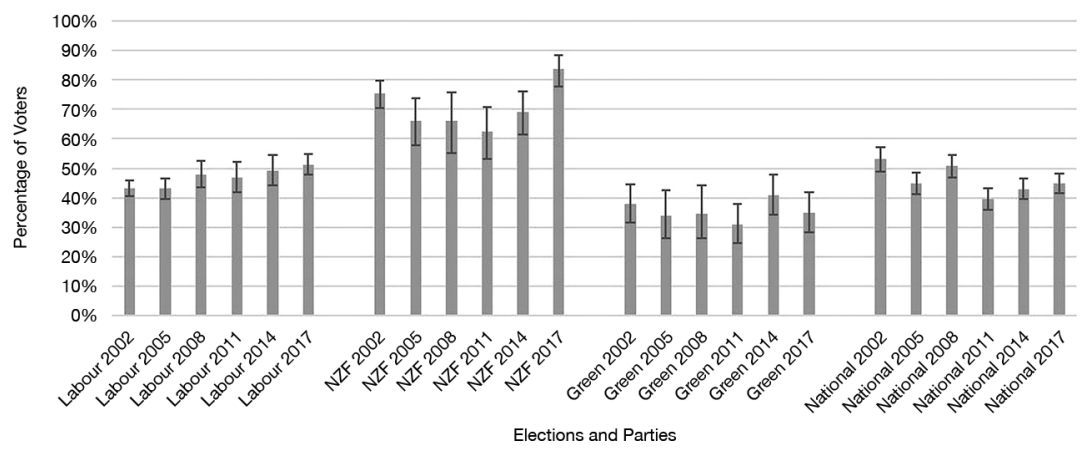

Figure 5.11: Percentage of voters wanting immigration reduced a lot or a little by party preference.

Source: New Zealand Election Study (2017).

We tested the association between people's votes and their views on immigration. With no controls, wanting lower immigration was associated with an increased probability of voting for New Zealand First rather than for National, to a lesser extent with voting for Labour rather than National and with a reduced chance of voting for the Green Party rather than National (see Table A5.3). With controls for populism, nativism, authoritarianism and a voter's left-right position added, wanting reduced immigration remained associated with voting for New Zealand First rather than National; however, the results for voting for Labour and the Green Party were no longer statistically significant (see Table A5.4). Controlling for views on immigration, populism and nativism both had statistically significant positive effects on people voting for New Zealand First, Labour and for being non-voters, rather than voting for National. Further, populism had statistically significant positive effects on whether people voted for the Green Party, rather than for National, while authoritarianism had significant negative effects on numbers voting for Labour and the Green Party rather than voting for National. The left-right control is significant for all parties, indicating the continuing significance of views regarding economic policy and redistribution on voting. 
We then repeated the analysis, but with 'wanting to reduce immigration' supplemented with more specific variables regarding the effects of immigration on New Zealand's economy and culture (see Table A5.5). All four variables measuring views on immigration helped to explain voting for New Zealand First rather than National. After controlling for populism, nativism and authoritarianism, both wanting to reduce immigration and believing immigrants were bad for the economy were associated with voting for New Zealand First rather than National (see Table A5.6). Compared to those who voted for National, non-voters were also more likely to want to reduce immigration and believe that immigration was bad for the economy. Labour voters were less likely than National voters to believe that immigrants cause crime, although this variable was only significant at a 10 per cent level.

\section{Discussion and Conclusion}

Was New Zealand a 'populist exception' in 2017 in terms of immigration? On balance, we believe the results above indicate that it was, at least regarding exclusionary forms of anti-immigration populist rhetoric and policy. In terms of demand, a proportion of New Zealanders continued to respond positively to New Zealand First's brand of populism, however, that proportion has decreased rather than increased over the previous three years. In terms of supply, National, Labour, the Greens, ACT and the Māori Party all explicitly rejected rhetoric that stigmatised or sought to marginalise minorities and immigrants in 2017. This reduced the supply of anti-immigration exclusionary populism on offer for the nearly 50 per cent of New Zealanders who wanted immigration reduced.

None of this, however, is to suggest that right-wing, exclusionary or even authoritarian populism has no future in New Zealand. On the supply side, we may observe more players entering the immigration policy arena. New Zealand First's historical ownership of the immigration issue, which had been facilitated both by the bi-partisan support for immigration by the two major parties and by the absence of an anti-immigration party to the right of National, was challenged by National and Labour's willingness to debate immigration in 2017. While neither of the major parties seem likely to abandon their support for large-scale immigration, both offered more restrictive immigration policies in 2017. This could be read as evidence of those parties being subject to a 'contagion' effect (van Spanje, 2010) 
from New Zealand First, but might also be interpreted as both parties inoculating themselves and public discourse against such contagion by demonstrating receptivity to public concerns regarding immigration. After all, National and Labour have tended to exert a moderating influence on New Zealand First's approach to immigration during the periods in which they have relied on New Zealand First to govern.

However, it is not inconceivable that one or the other party will also begin to offer more exclusionary rhetoric when discussing immigration. National and ACT are both reported to have worked with political consulting firm Crosby Textor, credited with much of the Australian Liberal Party's anti-asylum rhetoric and policies and the British Conservative Party's anti-immigration messages since the early 2000s (Hager, 2006; LeesMarshment, 2009). Under Don Brash's leadership (2003-2006), National demonstrated its willingness to engage in racially divisive campaigning when promising to deliver votes (Brash, 2004; Hager, 2006). Nor is it impossible that a political entrepreneur might see an opportunity in National's lack of a viable coalition partner and establish a populist, anti-immigration party to its right.

On the demand side, changes in New Zealand's immigration policy settings that have, over the last couple of decades, seen temporary migration heavily outweigh settler migration, may also alter the way that New Zealanders assess the economic, social and cultural costs and benefits of immigration. A growing under-class of immigrants who are denied access to permanent residency and, thus, to voting rights, whose vulnerable visa status makes them targets of exploitative employers and landlords, and who may compete with New Zealanders for unskilled work, has the potential to undermine New Zealanders' generally positive views regarding the economic and social effects of immigration. Unaffordable housing, growing inequality and the perception that immigrants are competing for low-skilled jobs are all variables that we have seen correlate with a desire to see immigration reduced and a growing electoral salience of immigration.

Some of the institutional settings that may have contributed to New Zealand's immigration politics to date are also under strain. Most significantly, social media and digital campaigning techniques have decreased the central role that the mainstream media have traditionally played in election campaigns. As discussed, New Zealand's mainstream print and broadcast media are, either voluntarily or by statute, committed 
to provide fair, balanced and accurate reportage on issues of public contention. Growing use of Facebook, YouTube, WhatsApp and any number of other social media will continue to undermine the ability of the mainstream media to authoritatively shape public debate in a way that conforms to the balance, fairness and accuracy requirements placed upon them. Similarly, the replacement of traditional mass election campaigning with digital campaign techniques involving highly targeted and temporary messages to individual voters, invisible to those to whom they are not targeted, has made exclusionary, populist politics both more feasible and more profitable for parties willing to engage in them.

Immigration has proved to be a particularly volatile addition to the alchemic electoral politics of democracies. Any combination of changes to the supply and demand variables identified above, or to the institutional and international settings within which they operate, has the potential to undermine New Zealand's status as a country that has largely avoided the most virulent strains of anti-immigration exclusionary populism.

\section{References}

Bahador, B., Boyd, M. \& Roff, K. (2016). Media coverage of New Zealand elections: 2008-14. In G. Kemp, B. Bahador \& C. Rudd (Eds), Politics and the media (2nd ed.) (pp. 201-218). Auckland, New Zealand: Auckland University Press.

Barker, F. (2018). Immigration and the Key-English government. In S. Levine (Ed.), Stardust and substance: The New Zealand general election of 2017 (pp. 265-280). Wellington, New Zealand: Victoria University Press.

Barker, F. \& McMillan, K. (2014). Constituting the democratic public: New Zealand's extension of national voting rights to non-citizens. New Zealand Journal of Public \& International Law, 12(1), 61-80.

Bartle, J., Sanders, D. \& Twyman, J. (2020). Authoritarian populist opinion in Europe. In I. Crewe and D. Sanders (Eds), Authoritarian populism and liberal democracy (pp. 49-71). Cham, Switzerland: Palgrave Macmillan. doi.org/ 10.1007/978-3-030-17997-7_4

British Broadcasting Corporation. (2019). Europe and right-wing nationalism: A country by country guide. Retrieved from www.bbc.com/news/worldeurope-36130006 
Betz, H.-G. (2002). Conditions favouring the success and failure of radical rightwing populist parties in contemporary democracies. In Y Mény \& Y. Surel (Eds), Democracies and the populist challenge (pp. 197-212). London, United Kingdom: Palgrave Macmillan. doi.org/10.1057/9781403920072_11

Betz, H.-G. \& Johnson, C. (2004). Against the current-Stemming the tide: The nostalgic ideology of the contemporary radical populist right. Journal of Political Ideologies, 9(3), 311-27. doi.org/10.1080/1356931042000263546

Brash, D. (2004, 28 January). Nationhood (Address to the Orewa Rotary Club). New Zealand Herald. Retrieved from www.nzherald.co.nz/treaty-of-waitangi/ news/article.cfm?c_id=350\&objectid=3545950

Burr, L. \& Gower, P. (2017). Jacinda Ardern rejects Trump comparison in Wall St Journal. Newshub. Retrieved from www.newshub.co.nz/home/election/2017/ 09/jacinda-ardern-rejects-trump-comparison-in-wall-street-journal.html

Cameron, S. \& McAllister, I. (2019). The 2019 Federal Election: Results from the Australian Election Study. Canberra: ANU College of Arts \& Social Sciences, School of Politics \& International Relations. Retrieved from australianelectionstudy.org/wp-content/uploads/The-2019-AustralianFederal-Election-Results-from-the-Australian-Election-Study.pdf

Campbell, G. (2017). Gordon Campbell on Labour's anti-immigration gambit and Israel. Blog. Retrieved from werewolf.co.nz/2017/06/gordon-campbellon-labours-anti-immigration-gambit-and-israel/

Card, D., Dustmann, C. \& Preston, I. (2005). Understanding attitudes to immigration: The migration and minority module of the first European Social Survey. London, United Kingdom: University College. Retrieved from davidcard.berkeley.edu/papers/euroimmig.pdf

Cochrane, B. \& Poot, J. (2019). The effects of immigration on local housing markets. Hamilton, New Zealand: University of Waikato. Retrieved from ideas.repec. org/p/wai/econwp/19-07.html

Collins, F. (2017). We are creating a guest-worker programme. New Zealand Herald. Retrieved from www.nzherald.co.nz/opinion/news/article.cfm?c_id= 4668 \&objectid $=11841828$

Comparative Study of Electoral Systems. (2019, 21 May). CSES Module 5 First Advance Release [dataset and documentation]. Ann Arbor, MI: CSES. doi.org/ 10.7804/cses.module5.2019-05-21

Concern over migrant 'exploitation' in Queenstown. (2015). Television New Zealand. Retrieved from www.tvnz.co.nz/one-news/new-zealand/concernover-migrant-exploitation-in-queenstown-6249237 
Crothers, C. (2014). Immigrants and voting in New Zealand. In J. Vowles (Ed.), The new electoral politics in New Zealand: The significance of the 2011 election (pp. 161-183). Wellington, New Zealand: Institute of Policy Studies.

Davison, I. (2017). Government to backtrack on immigration cuts. New Zealand Herald. Retrieved from www.nzherald.co.nz/business/news/article.cfm?c_id= 3\&objectid= 11894306

DeAngelis, R. (1998). Pauline Hanson's One Nation Party: Xenophobic populism compared. Policy, Organisation and Society, 16(1), 1-27. doi.org/10.1080/ 10349952.1998.11876687

Denemark, D. \& Bowler, S. (2002). Minor parties and protest votes in Australia and New Zealand: Locating populist politics. Electoral Studies, 21, 47-67. doi.org/10.1016/S0261-3794(00)00034-2

Doing our bit. (2018). Double the quota. Retrieved from www.doingourbit.co.nz/

Donovan, T. \& D. Redlawsk. (2018). Donald Trump and right-wing populists in comparative perspective. Journal of Elections, Public Opinion and Parties, 28(2), 190-207. doi.org/10.1080/17457289.2018.1441844

Dozens of employers under Immigration NZ investigation for alleged immigration fraud. (2017). New Zealand Herald. Retrieved from www.nzherald.co.nz/nz/ news/article.cfm?c_id=1\&objectid=11876111

Eatwell, R. \& Goodwin, M. (2018). National populism: The revolt against liberal democracy. London, United Kingdom: Pelican.

Edo, A. (2019). The impact of immigration on the labour market. Journal of Economic Surveys, 33(3), 922-948. doi.org/10.1111/joes.12300

Edwards, B. (2017). Labour's Goldilocks immigration policy. New Zealand Herald. Retrieved from www.nzherald.co.nz/nz/news/article.cfm?c_id=1\& objectid $=11875398$

Global House Prices. (2017). Economist, 422(9031), 76.

Golder, M. (2016). Far right parties in Europe. Annual Review of Political Science, 19(1), 477-497. doi.org/10.1146/annurev-polisci-042814-012441

Hager, N. (2006). The hollow men. A study in the politics of deception. Nelson, New Zealand: Craig Potton.

Hainmueller, J. \& Hiscox, M. J. (2007). Educated preferences: Explaining attitudes toward immigration in Europe. International Organization, 61(2), 399-442. doi.org/10.1017/s0020818307070142 
Ipsos. (2018). What New Zealanders think of refugees and immigration. Scoop. Retrieved from www.scoop.co.nz/stories/PO1809/S00232/what-newzealanders-think-of-refugees-and-immigration.htm

Ipsos Mori. (2020). Issues Index: 2007 onwards. doi.org/10.4135/9781473969490

James Shaw 'sorry' after immigration policy slammed as racist. (2017). Newshub. Retrieved from www.newshub.co.nz/home/politics/2017/07/james-shawsorry-after-immigration-policy-slammed-as-racist.html

Jayasinghe, P. \& Ratnayake, S. (2017). Migration, opportunity and betrayal: $A$ personal retrospective. Retrieved from www.pantograph-punch.com/post/ migration-opportunity-betrayal-personal-retrospective

Jones, J. M. (2019). New high in U.S. Say immigration most important problem. Gallup. Retrieved from news.gallup.com/poll/259103/new-highsay-immigration-important-problem.aspx

Jones, N. (2017). Act's David Seymour condemns national for starting 'populist bidding war' on immigration. New Zealand Herald. Retrieved from www.nzherald.co.nz/business/news/article.cfm?c_id=3\&objectid=11842659

Kimmorley, S. (2017). Malcolm Turnbull axes 457 visa program for skilled migration, saying he's 'putting Australians first'. Business Insider. Retrieved from www.businessinsider.com.au/turnbull-scraps-457-visas-forskilled-workers-2017-4

Kosiara-Pedersen, K. (2019). Stronger core, weaker fringes: The Danish General Election 2019. WestEuropean Politics, 1-12. doi.org/10.1080/01402382.2019. 1655920

Kyle, J. \& Gultchin, L. (2018). Populists in power around the world. Retrieved from institute.global/insight/renewing-centre/populists-power-around-world

Labour Party of New Zealand. (2017). Making immigration work for New Zealand. Retrieved from www.labour.org.nz/immigration

Laxon, A. (2016). Student visa fraud: 'It's not about education'. New Zealand Herald. Retrieved from www.nzherald.co.nz/nz/news/article.cfm?c_id=1\& objectid=11759352

Lees-Marshment, J. (2009). Political marketing: Principles and applications. London, United Kingdom: Routledge. 
MacDonald, D. B. (2019). Between populism and pluralism: Winston Peters and the international relations of New Zealand First. In F. Stengel, D. MacDonald $\&$ D. Nabers (Eds), Populism and world politics. Global political sociology (pp. 227-247). Cham, Switzerland: Palgrave Macmillan. doi.org/10.1007/ 978-3-030-04621-7_9

Malhotra, N., Margalit, Y. \& Mo, C. H. (2013). Economic explanations for opposition to immigration: Distinguishing between prevalence and conditional impact. American Journal of Political Science, 57(2), 391-410. doi.org/10.1111/ajps.12012

Maori Party. (2017). Immigration policy. Retrieved from www.maoriparty.org/ immigration_policy_2017

Markaki, Y. \& Longhi, S. (2013). What determines attitudes to immigration in European countries? An analysis at the regional level. Migration Studies, 1(3), 311-337. doi.org/10.1093/migration/mnt015

McBeth, P. (2017). Woodhouse unveils 'Kiwi First' immigration policy with new work visa rules. National Business Review. Retrieved from www.nbr.co.nz/ article/woodhouse-unveils-kiwis-first-immigration-policy-new-work-visarules-b-202034

McCrow-Young, A. (2017). Why I really want to vote Labour but can't. The Spinoff. Retrieved from thespinoff.co.nz/politics/12-09-2017/why-i-really-want-tovote-labour-but-i-cant/

McKenzie, D. (2017). Migration hits 72,000. Otago Daily Times. Retrieved from www.odt.co.nz/business/migration-hits-72000-0

McMillan, K. (2005). Immigration, nationalism and citizenship debates in the 1990s. In A. Trlin, P. Spoonley \& N. Watts (Eds), New Zealand and international migration: A digest and bibliography (pp. 70-85). Palmerston North, New Zealand: Massey University.

McMillan, K. (2017a). Oppose, deflect, defuse, adopt? Framing immigration in the main parties. 2017 campaign speeches and press releases. Wellington, New Zealand: Victoria University Press.

McMillan, K. (2017b, November). Samuel Drew Lecture: Where people settle, legends unfold: Immigration and electoral politics in Aotearoa/New Zealand (Paper presentation). Whanganui Regional Museum. 
McMillan, K. (2019). The intersecting electoral politics of immigration and inequality in Aotearoa/New Zealand. In R. Simon-Kumar, F. L. Collins and W. Friesen (Eds), Intersections of inequality, migration and diversification: The politics of mobility in Aorearoa/New Zealand (pp. 87-108). Cham, Switzerland: Palgrave Macmillan. doi.org/10.1007/978-3-030-19099-6_5

Moffit, B. (2017). Populism in Australia and New Zealand. In C. R. Kaltwasser, P. A. Taggart, P. O. Espejo \& P. Ostiguy (Eds), The Oxford handbook of populism (pp. 1-21). Oxford, United Kingdom: Oxford University Press. doi.org/10.1093/oxfordhb/9780198803560.013.5

Mudde, C. \& Kaltwasser, C. R. (2013). Exclusionary vs. inclusionary populism: Comparing contemporary Europe and Latin America. Government and Opposition, 48(2), 147-174. doi.org/10.1017/gov.2012.11

New Zealand Election Study. (2017). New Zealand Election Study [dataset]. Retrieved from www.nzes.org/exec/show/data

New Zealand Government [Hansard]. (2017). New Zealand Parliamentary Debates, official Hansard. Retrieved from www.parliament.nz/resource/enNZ/HansD_20170606_20170606/40bc87c280d0a0c01e84975a38087 1195be05d33

New Zealand Herald Business Desk. (2017, 21 August). New Zealand migration hits new record in July, despite more Kiwis leaving. New Zealand Herald. Retrieved from www.nzherald.co.nz/business/news/article.cfm?c_id=3\& objectid=11908114

New Zealand Labour Party. (2017). Immigration. Retrieved from www.labour. org.nz/immigration

New Zealand Media Council. (2020). Statement of principles. Wellington, New Zealand: New Zealand Media Council. Retrieved from www.mediacouncil. org.nz/principles

Norris, P. \& Inglehart, R. (2019). Cultural backlash: Trump, Brexit and authoritarian populism. Cambridge, United Kingdom: Cambridge University Press. doi.org/10.1017/9781108595841

O'Rourke, K. H. \& Sinnott, R. (2006). The determinants of individual attitudes towards immigration. European Journal of Political Economy, 22(4), 838-861. doi.org/10.1016/j.ejpoleco.2005.10.005

Pasley, J. (2017). Wall Street Journal compares Labour's leader Jacinda Ardern to Donald Trump. Stuff. Retrieved from www.stuff.co.nz/national/politics/ 96519787/wall-street-journal-compares-labour-leader-jacinda-ardern-todonald-trump 
Perry, B. (2019). Household incomes in New Zealand: Trends in inequality and hardship 1982 to 2018. Wellington, New Zealand: Ministry of Social Development.

Peters, W. (2005). The end of tolerance. Speech to Far North Grey Power. Scoop. Retrieved from www.scoop.co.nz/stories/PA0507/S00649.htm

PWC. (2019). Competitive cities: A decade of shifting fortunes. Auckland, New Zealand: PWC New Zealand. Retrieved from www.pwc.co.nz/publications/ 2019/citiesinstitute/cities-urban-competitivesness-tech-report-4.0.pdf

Rutherford, H. (2015). Could the Chinese-sounding names stunt be Labour's Orewa? Stuff. Retrieved from www.stuff.co.nz/national/politics/70225493/

Rutherford, H. (2017). NZ's net migration gain still at record highs near 72,000 as numbers continue to climb. Stuff. Retrieved from www.stuff.co.nz/business/ 91921252/net-migration-gain-near-72000-as-arrivals-continue-to-climb

Schrader, B. (2018). Crisis? What crisis? An overview of the fifth National Government's housing policies. In S. Levine (Ed.), Stardust and substance: The New Zealand general election of 2017 (pp. 281-295). Wellington, New Zealand: Victoria University Press.

Sharpe, J. (2019). Re-evaluating the impact of immigration on the US rental housing market. Journal of Urban Economics, 111, 14-34. doi.org/10.1016/ j.jue.2019.04.001

Speedy, E. \& Bryant, R. (2016). Widespread fraud found among education agents representing Indian students. Stuff. www.stuff.co.nz/national/education/ 81386128/widespread-fraud-found-among-education-agencies-representingindian-students

Spoonley, P. (2017). Opinion immigration-Here we go again. Massey University News. Retrieved from www.massey.ac.nz/massey/about-massey/news/article. cfm?mnarticle_uuid=94140180-EACD-165C-A5F8-CB83EFF319CA

Statistics New Zealand. (2017). Annual net gain reaches a record 72,400. Retrieved from archive.stats.govt.nz/browse_for_stats/population/Migration/IntTravel AndMigration_MRJul17.aspx

Statistics New Zealand. (2019). Birthplace and people born overseas. Retrieved from archive.stats.govt.nz/Census/2013-census/profile-and-summary-reports/ quickstats-culture-identity/birthplace.aspx

Tan, L. (2017). New Zealand migration at new record highs, arrivals on the rise. New Zealand Herald. Retrieved from www.nzherald.co.nz/nz/news/article. cfm?c_id=18objectid=11845494 
Thousands turn out to protest TPP. (2015, 15 August). Radio New Zealand. Retrieved from www.rnz.co.nz/news/political/281466/thousands-turn-out-toprotest-tpp

Towle, M. (2016). Government happy with farm conditions monitoring. Radio New Zealand. Retrieved from www.rnz.co.nz/news/national/293902/govthappy-with-farm-conditions-monitoring

Tupou, L. (2017). Migrant worker describes 'modern day slavery' scam. Radio New Zealand. Retrieved from www.rnz.co.nz/news/national/339373/migrantworker-describes-modern-day-slavery-scam

van Spanje, J. (2010). Contagious parties: Anti-immigration parties and their impact on other parties-Immigration stances in contemporary Western Europe. Party Politics, 16(5), 563-86. doi.org/10.1177/1354068809346002

Vowles, J, Coffé, H. \& Curtin, J. (2017). A bark but no bite: Inequality and the 2014 New Zealand general election (pp. 165-188). Canberra, Australia: ANU Press. doi.org/10.22459/BBNB.08.2017

Wagner, M. \& Meyer, T. M. (2016). The radical right as niche parties? The ideological landscape of party systems in Western Europe, 1980-2014. Political Studies, 65(1, Suppl.), 84-107. doi.org/10.1177/0032321716639065

Ward, C., Masgoret, A-M. \& Vauclair, M. (2011). Attitudes towards immigrants and immigrants' experiences: Predictive models based on regional characteristics. Wellington, New Zealand: New Zealand Department of Labour.

Wilson, J. (2005). History-Māori arrival and settlement. Retrieved from www.TeAra.govt.nz/en/history/page-1

Woodhouse, M. (2017). Speech outlining the Government's plans for immigration. Retrieved from www.national.org.nz/speech_outlining_the_government_s_ plan_for_immigration 


\section{Appendices}

Table A5.1: The social and demographic correlates of immigration opinion

\begin{tabular}{|c|c|c|c|c|}
\hline \multirow[b]{2}{*}{ Variables } & \multicolumn{4}{|c|}{ Model } \\
\hline & $\begin{array}{c}\text { (1) } \\
\text { Reduce } \\
\text { immigration }\end{array}$ & $\begin{array}{c}\text { (2) } \\
\text { Immigrants } \\
\text { good } \\
\text { Economy }\end{array}$ & $\begin{array}{l}\text { (3) } \\
\text { Immigrants bad } \\
\text { New Zealand } \\
\text { culture }\end{array}$ & $\begin{array}{c}\text { (4) } \\
\text { Immigrants } \\
\text { cause crime }\end{array}$ \\
\hline \multirow[t]{2}{*}{ Māori (European) } & $0.388^{\star \star}$ & -0.205 & $0.536^{\star \star \star}$ & 0.171 \\
\hline & (0.161) & (0.162) & $(0.167)$ & (0.201) \\
\hline \multirow{2}{*}{$\begin{array}{l}\text { Pasifika } \\
\text { (European) }\end{array}$} & 0.195 & 0.703 & 0.0311 & $0.758^{*}$ \\
\hline & $(0.401)$ & $(0.514)$ & $(0.473)$ & $(0.447)$ \\
\hline \multirow[t]{2}{*}{ Asian (European) } & -0.255 & $1.155^{\star \star \star}$ & $-0.740^{\star \star}$ & $-0.675^{\star}$ \\
\hline & $(0.276)$ & (0.349) & $(0.350)$ & (0.363) \\
\hline \multirow[t]{2}{*}{ Other (European) } & -1.217 & & 0.350 & -0.555 \\
\hline & $(0.785)$ & & $(0.759)$ & $(1.181)$ \\
\hline \multirow[t]{2}{*}{ Age } & $0.0539^{\star \star \star}$ & $-0.0448^{\star}$ & $0.0441^{*}$ & $0.0531^{\star}$ \\
\hline & (0.0203) & $(0.0231)$ & $(0.0261)$ & $(0.0271)$ \\
\hline \multirow[t]{2}{*}{ Age squared } & $-0.000426^{\star \star}$ & $0.000636^{\star \star \star}$ & -0.000364 & $-0.000486^{\star \star}$ \\
\hline & (0.000187) & (0.000215) & (0.000255) & (0.000245) \\
\hline \multirow[t]{2}{*}{ Female } & $-0.185^{\star}$ & 0.0420 & $-0.452^{\star \star \star}$ & $-0.491^{\star \star \star}$ \\
\hline & (0.104) & (0.118) & $(0.131)$ & (0.152) \\
\hline \multirow{2}{*}{$\begin{array}{l}\text { School } \\
\text { qualification }\end{array}$} & $-0.317^{\star *}$ & 0.139 & -0.218 & $-0.528^{\star \star \star}$ \\
\hline & (0.160) & $(0.176)$ & $(0.178)$ & $(0.204)$ \\
\hline \multirow{2}{*}{$\begin{array}{l}\text { Tertiary } \\
\text { qualification }\end{array}$} & -0.165 & 0.0905 & $-0.394^{\star *}$ & $-0.460^{\star *}$ \\
\hline & $(0.168)$ & $(0.184)$ & $(0.183)$ & $(0.206)$ \\
\hline \multirow[t]{2}{*}{ University degree } & $-0.372^{\star \star}$ & $0.667^{\star \star \star}$ & $-0.648^{\star \star \star}$ & $-1.548^{\star \star \star}$ \\
\hline & $(0.171)$ & $(0.192)$ & $(0.211)$ & $(0.266)$ \\
\hline \multirow[t]{2}{*}{ Income quintile } & $-0.0926^{\star \star}$ & 0.0372 & $-0.193^{\star \star \star}$ & $-0.187^{\star *}$ \\
\hline & (0.0452) & $(0.0509)$ & (0.0552) & $(0.0745)$ \\
\hline \multirow[t]{2}{*}{ Future prospects } & $-0.148^{\star}$ & $0.538^{\star \star \star}$ & $-0.243^{\star \star}$ & -0.146 \\
\hline & (0.0863) & $(0.0958)$ & $(0.108)$ & $(0.137)$ \\
\hline \multirow[t]{2}{*}{ Urban } & 0.0267 & $0.263^{\star \star}$ & 0.189 & -0.0196 \\
\hline & (0.114) & $(0.130)$ & $(0.138)$ & (0.159) \\
\hline \multirow{2}{*}{$\begin{array}{l}\text { Own home with } \\
\text { mortgage }\end{array}$} & 0.121 & -0.174 & 0.268 & -0.0767 \\
\hline & (0.137) & $(0.156)$ & (0.208) & $(0.226)$ \\
\hline
\end{tabular}




\begin{tabular}{|c|c|c|c|c|}
\hline \multirow[b]{2}{*}{ Variables } & \multicolumn{4}{|c|}{ Model } \\
\hline & $\begin{array}{c}\text { (1) } \\
\text { Reduce } \\
\text { immigration }\end{array}$ & $\begin{array}{c}\text { (2) } \\
\text { Immigrants } \\
\text { good } \\
\text { Economy }\end{array}$ & $\begin{array}{c}\text { (3) } \\
\text { Immigrants bad } \\
\text { New Zealand } \\
\text { culture }\end{array}$ & $\begin{array}{c}\text { (4) } \\
\text { Immigrants } \\
\text { cause crime }\end{array}$ \\
\hline \multirow[t]{2}{*}{ Family renting } & $0.333^{\star}$ & -0.235 & $0.671^{\star \star \star}$ & 0.394 \\
\hline & $(0.200)$ & $(0.213)$ & $(0.257)$ & $(0.301)$ \\
\hline \multirow[t]{2}{*}{ Public housing } & -0.203 & $-1.734^{\star \star \star *}$ & $0.810^{\star \star}$ & $0.684^{\star}$ \\
\hline & $(0.317)$ & $(0.296)$ & $(0.348)$ & $(0.386)$ \\
\hline \multirow[t]{2}{*}{ Board or hostel } & 0.561 & -0.554 & $0.831^{\star \star}$ & 0.428 \\
\hline & (0.369) & $(0.448)$ & $(0.391)$ & $(0.503)$ \\
\hline \multirow{2}{*}{$\begin{array}{l}\text { Flatting with } \\
\text { friends }\end{array}$} & -0.219 & -0.229 & 0.437 & -0.0729 \\
\hline & $(0.336)$ & $(0.379)$ & $(0.386)$ & $(0.501)$ \\
\hline \multirow{2}{*}{$\begin{array}{l}\text { Live with family } \\
\text { members }\end{array}$} & 0.236 & $-0.742^{\text {***}}$ & 0.371 & 0.153 \\
\hline & $(0.275)$ & $(0.280)$ & $(0.311)$ & $(0.425)$ \\
\hline \multirow[t]{2}{*}{ Constant } & -0.830 & 0.0420 & $-1.568^{\star \star}$ & $-1.587^{\star}$ \\
\hline & (0.633) & $(0.723)$ & $(0.726)$ & $(0.914)$ \\
\hline Observations & 3,270 & 3,258 & 3,270 & 3,270 \\
\hline $\begin{array}{l}\text { Pseudo } \\
\text { R-squared }\end{array}$ & 0.0353 & 0.0895 & 0.0700 & 0.0917 \\
\hline
\end{tabular}

Note: Robust standard errors in parentheses.

${ }^{\star \star \star} \mathrm{p}<0.01,{ }^{\star \star} \mathrm{p}<0.05,{ }^{\star} \mathrm{p}<0.1$.

Source: New Zealand Election Study (2017).

Table A5.2: Attitudinal correlates of preferences to reduce immigration or not

\begin{tabular}{|c|c|c|c|c|c|}
\hline \multirow[b]{2}{*}{ Variables } & \multicolumn{5}{|c|}{ Model } \\
\hline & $\begin{array}{c}\text { (1) } \\
\text { Reduce } \\
\text { immigration }\end{array}$ & $\begin{array}{c}\text { (2) } \\
\text { Reduce } \\
\text { immigration }\end{array}$ & $\begin{array}{c}\text { (3) } \\
\text { Reduce } \\
\text { immigration }\end{array}$ & $\begin{array}{c}\text { (4) } \\
\text { Reduce } \\
\text { immigration }\end{array}$ & $\begin{array}{c}\text { (5) } \\
\text { Reduce } \\
\text { immigration }\end{array}$ \\
\hline \multirow[t]{2}{*}{ Populism } & $1.961^{\star \star \star}$ & $0.734^{\star \star}$ & $0.696^{\star \star}$ & -0.125 & -0.0851 \\
\hline & $(0.287)$ & $(0.335)$ & $(0.341)$ & $(0.370)$ & $(0.381)$ \\
\hline \multirow[t]{2}{*}{ Authoritarianism } & $0.952^{\star \star \star}$ & 0.0798 & -0.191 & $0.757^{\star *}$ & 0.437 \\
\hline & $(0.248)$ & $(0.283)$ & $(0.284)$ & $(0.318)$ & $(0.318)$ \\
\hline \multirow[t]{2}{*}{ Efficacy } & $0.890^{\star \star \star}$ & $1.418^{\star \star \star}$ & $1.184^{\star \star \star}$ & $1.268^{\star \star \star}$ & $1.062^{\star \star \star}$ \\
\hline & $(0.244)$ & $(0.271)$ & $(0.267)$ & $(0.273)$ & $(0.272)$ \\
\hline \multirow{2}{*}{$\begin{array}{l}\text { Good for } \\
\text { economy }\end{array}$} & & $-0.574^{\star \star \star}$ & $-0.608^{\star \star \star}$ & $-0.575^{\star \star *}$ & $-0.605^{\star \star \star}$ \\
\hline & & $(0.0746)$ & (0.0769) & $(0.0761)$ & $(0.0783)$ \\
\hline \multirow[t]{2}{*}{ Bad for culture } & & $0.339^{\star \star \star}$ & $0.289^{\star \star \star}$ & $0.343^{\star \star \star}$ & $0.295^{\star \star \star}$ \\
\hline & & $(0.0630)$ & $(0.0606)$ & $(0.0612)$ & $(0.0597)$ \\
\hline
\end{tabular}




\begin{tabular}{|c|c|c|c|c|c|}
\hline \multirow[b]{2}{*}{ Variables } & \multicolumn{5}{|c|}{ Model } \\
\hline & $\begin{array}{c}\text { (1) } \\
\text { Reduce } \\
\text { immigration }\end{array}$ & $\begin{array}{c}\text { (2) } \\
\text { Reduce } \\
\text { immigration }\end{array}$ & $\begin{array}{c}\text { (3) } \\
\text { Reduce } \\
\text { immigration }\end{array}$ & $\begin{array}{c}\text { (4) } \\
\text { Reduce } \\
\text { immigration }\end{array}$ & $\begin{array}{c}\text { (5) } \\
\text { Reduce } \\
\text { immigration }\end{array}$ \\
\hline \multirow[t]{2}{*}{ Bad for crime } & & $0.142^{\star \star}$ & $0.129^{*}$ & $0.165^{\star \star}$ & $0.151^{\star \star}$ \\
\hline & & (0.0692) & (0.0693) & $(0.0694)$ & (0.0699) \\
\hline \multirow{2}{*}{$\begin{array}{l}\text { Spend more } \\
\text { housing }\end{array}$} & & & & 0.0958 & 0.0886 \\
\hline & & & & $(0.0801)$ & $(0.0805)$ \\
\hline \multirow[t]{2}{*}{ Support unions } & & & & $0.800^{\star \star \star}$ & $0.784^{\star \star *}$ \\
\hline & & & & (0.289) & $(0.285)$ \\
\hline \multirow{2}{*}{$\begin{array}{l}\text { Support } \\
\text { redistribution }\end{array}$} & & & & $1.279^{\star \star \star}$ & $1.134^{\star \star \star}$ \\
\hline & & & & (0.354) & (0.354) \\
\hline \multirow{2}{*}{$\begin{array}{l}\text { Cultural } \\
\text { conformity }\end{array}$} & & & $1.327^{\star \star \star}$ & & $1.235^{\star \star \star}$ \\
\hline & & & $(0.229)$ & & $(0.230)$ \\
\hline \multirow[t]{2}{*}{ Nativism } & & & 0.0774 & & 0.0923 \\
\hline & & & $(0.227)$ & & $(0.234)$ \\
\hline \multirow[t]{2}{*}{ Constant } & $-2.238^{\star \star *}$ & -0.637 & $-0.937^{\star \star}$ & $-2.088^{\star \star \star}$ & $-2.256^{\star \star \star}$ \\
\hline & $(0.252)$ & $(0.424)$ & $(0.426)$ & $(0.484)$ & $(0.478)$ \\
\hline $\begin{array}{l}\text { Pseudo-R } \\
\text { squared }\end{array}$ & 0.0394 & 0.1353 & 0.1537 & 0.1513 & 0.1670 \\
\hline Observations & $3,455.000$ & $3,455.000$ & $3,455.000$ & $3,455.000$ & $3,455.000$ \\
\hline
\end{tabular}

Note: Robust standard errors in parentheses.

${ }^{\star \star \star} \mathrm{p}<0.01,{ }^{* \star} \mathrm{p}<0.05,{ }^{*} \mathrm{p}<0.1$.

Source: New Zealand Election Study (2017).

Table A5.3: Immigration opinion and the party vote without attitudinal controls

\begin{tabular}{|l|c|c|c|c|c|}
\hline \multirow{2}{*}{ Variables } & \multicolumn{5}{|c|}{ Model } \\
\cline { 2 - 6 } & $\begin{array}{c}(\mathbf{1}) \\
\text { Nonvote }\end{array}$ & $\begin{array}{c}\text { (2) } \\
\text { Labour }\end{array}$ & $\begin{array}{c}\text { (4) } \\
\text { Green }\end{array}$ & $\begin{array}{c}\text { (5) } \\
\text { NZ_First }\end{array}$ & $\begin{array}{c}\text { (6) } \\
\text { Other }\end{array}$ \\
\hline \multirow{2}{*}{$\begin{array}{l}\text { Reduce } \\
\text { immigration }\end{array}$} & -0.050 & $0.255^{\star \star}$ & $-0.425^{\star \star}$ & $1.831^{\star \star \star}$ & -0.036 \\
\cline { 2 - 6 } & $(0.194)$ & $(0.099)$ & $(0.169)$ & $(0.206)$ & $(0.161)$ \\
\hline \multirow{2}{*}{ Constant } & $-0.483^{\star \star \star}$ & $-0.309^{\star \star *}$ & $-1.790^{\star \star \star}$ & $-3.031^{\star \star \star}$ & $-1.490^{\star \star \star}$ \\
\cline { 2 - 6 } & $(0.131)$ & $(0.070)$ & $(0.104)$ & $(0.180)$ & $(0.108)$ \\
\hline Observations & $3,438.00$ & $3,438.00$ & $3,438.00$ & $3,438.00$ & $3,438.00$ \\
\hline
\end{tabular}

Note: Robust standard errors in parentheses.

${ }^{* \star \star} \mathrm{p}<0.01,{ }^{\star *} \mathrm{p}<0.05,{ }^{*} \mathrm{p}<0.1$, Pseudo R2 0.0123 .

Source: New Zealand Election Study (2017). 
Table A5.4: Immigration and the party vote with attitudinal controls

\begin{tabular}{|c|c|c|c|c|c|}
\hline \multirow[b]{2}{*}{ Variables } & \multicolumn{5}{|c|}{ Model } \\
\hline & $\begin{array}{c}\text { (1) } \\
\text { Nonvote }\end{array}$ & $\begin{array}{c}\text { (2) } \\
\text { Labour }\end{array}$ & $\begin{array}{c}\text { (3) } \\
\text { Green }\end{array}$ & $\begin{array}{c}\text { (4) } \\
\text { NZ_First }\end{array}$ & $\begin{array}{c}\text { (5) } \\
\text { Other }\end{array}$ \\
\hline \multirow{2}{*}{$\begin{array}{l}\text { Reduce } \\
\text { immigration }\end{array}$} & -0.234 & 0.180 & -0.150 & $1.597^{\text {*** }}$ & -0.059 \\
\hline & (0.199) & (0.134) & (0.207) & $(0.220)$ & $(0.171)$ \\
\hline \multirow[t]{2}{*}{ Populism } & $3.272^{\star \star \star}$ & $3.938^{\star \star *}$ & $2.040^{\star \star \star}$ & $3.627^{\star \star \star}$ & $3.199^{\star \star \star}$ \\
\hline & $(0.728)$ & $(0.476)$ & $(0.760)$ & $(0.624)$ & $(0.555)$ \\
\hline \multirow[t]{2}{*}{ Nativism } & $1.069^{\star \star \star}$ & $0.742^{\star \star \star}$ & 0.458 & $0.748^{\star \star}$ & 0.232 \\
\hline & $(0.400)$ & $(0.273)$ & $(0.409)$ & $(0.325)$ & (0.328) \\
\hline \multirow[t]{2}{*}{ Authoritarianism } & -0.752 & $-2.127^{\star \star \star}$ & $-5.103^{\star \star \star}$ & 0.219 & $-2.317^{\star \star \star}$ \\
\hline & $(0.574)$ & $(0.426)$ & (0.624) & $(0.621)$ & $(0.470)$ \\
\hline \multirow[t]{2}{*}{ Left-right } & $-0.391^{\text {*** }}$ & $-0.717^{\star \star \star}$ & $-0.915^{\star \star \star}$ & $-0.323^{\star \star \star}$ & $-0.295^{\star \star \star}$ \\
\hline & $(0.061)$ & (0.061) & $(0.072)$ & (0.052) & $(0.045)$ \\
\hline \multirow[t]{2}{*}{ Constant } & 0.351 & $2.401^{\text {***}}$ & $3.569^{\star \star \star}$ & $-3.146^{\star \star \star}$ & -0.143 \\
\hline & $(0.463)$ & (0.363) & $(0.424)$ & $(0.417)$ & $(0.338)$ \\
\hline Observations & $3,438.000$ & $3,438.000$ & $3,438.000$ & $3,438.000$ & $3,438.000$ \\
\hline
\end{tabular}

Note: Robust standard errors in parentheses.

${ }^{\star * \star} p<0.01,{ }^{* \star} p<0.05,{ }^{*} p<0.1$. Pseudo R-squared 0.1550 .

Source: New Zealand Election Study (2017).

Table A5.5: Components of immigration attitudes and the party vote

\begin{tabular}{|c|c|c|c|c|c|}
\hline \multirow[b]{2}{*}{ Variables } & \multicolumn{5}{|c|}{ Model } \\
\hline & $\begin{array}{c}\text { (1) } \\
\text { Nonvote }\end{array}$ & $\begin{array}{c}\text { (2) } \\
\text { Labour }\end{array}$ & $\begin{array}{c}\text { (4) } \\
\text { Green }\end{array}$ & $\begin{array}{c}\text { (5) } \\
\text { NZ_First }\end{array}$ & $\begin{array}{l}\text { (6) } \\
\text { Other }\end{array}$ \\
\hline \multirow{2}{*}{$\begin{array}{l}\text { Reduce } \\
\text { immigration }\end{array}$} & $-0.452^{\star *}$ & 0.169 & $-0.308^{*}$ & $1.411^{\star \star \star}$ & -0.227 \\
\hline & $(0.220)$ & (0.105) & $(0.169)$ & $(0.223)$ & $(0.172)$ \\
\hline \multirow{2}{*}{$\begin{array}{l}\text { Immigrants } \\
\text { good economy }\end{array}$} & $-1.327^{\star \star \star}$ & $-0.556^{\star \star \star}$ & $-0.556^{\star \star \star}$ & $-0.734^{\star \star \star}$ & $-0.757^{\text {***}}$ \\
\hline & $(0.221)$ & $(0.118)$ & $(0.188)$ & $(0.190)$ & $(0.176)$ \\
\hline \multirow{2}{*}{$\begin{array}{l}\text { Immigrants } \\
\text { bad culture }\end{array}$} & 0.290 & 0.209 & $-0.665^{\star \star}$ & $0.592^{\star \star \star}$ & 0.174 \\
\hline & $(0.280)$ & $(0.151)$ & $(0.292)$ & $(0.217)$ & $(0.194)$ \\
\hline \multirow{2}{*}{$\begin{array}{l}\text { Immigrants } \\
\text { cause crime }\end{array}$} & 0.147 & $-0.451^{\star *}$ & $-1.088^{\star \star \star}$ & $0.474^{\star \star}$ & -0.025 \\
\hline & (0.301) & $(0.182)$ & (0.373) & $(0.216)$ & $(0.226)$ \\
\hline \multirow[t]{2}{*}{ Constant } & $0.471^{\star \star}$ & 0.156 & $-1.256^{\star \star \star}$ & $-2.562^{\star \star \star}$ & $-0.894^{\star \star \star}$ \\
\hline & $(0.215)$ & $(0.121)$ & $(0.177)$ & $(0.233)$ & $(0.176)$ \\
\hline Observations & $3,438.000$ & $3,438.000$ & $3,438.000$ & $3,438.000$ & $3,438.000$ \\
\hline
\end{tabular}

Note: Robust standard errors in parentheses.

${ }^{\star * \star} \mathrm{p}<0.01,{ }^{* *} \mathrm{p}<0.05,{ }^{\star} \mathrm{p}<0.1$, Pseudo R-squared 0.0365 .

Source: New Zealand Election Study (2017). 
Table A5.6: Populism, nativism, authoritarianism, components of immigration opinion and the party vote

\begin{tabular}{|c|c|c|c|c|c|}
\hline \multirow[t]{2}{*}{ Variables } & \multicolumn{5}{|c|}{ Model } \\
\hline & $\begin{array}{c}\text { (1) } \\
\text { Nonvote }\end{array}$ & $\begin{array}{c}\text { (2) } \\
\text { Labour }\end{array}$ & $\begin{array}{c}\text { (4) } \\
\text { Green }\end{array}$ & $\begin{array}{l}\text { (5) } \\
\text { NZ_First }\end{array}$ & $\begin{array}{c}\text { (6) } \\
\text { Other }\end{array}$ \\
\hline \multirow{2}{*}{$\begin{array}{l}\text { Reduce } \\
\text { immigration }\end{array}$} & $-0.449^{\star *}$ & 0.200 & -0.135 & $1.394^{\star \star *}$ & -0.180 \\
\hline & $(0.224)$ & $(0.138)$ & (0.209) & $(0.231)$ & (0.178) \\
\hline \multirow{2}{*}{$\begin{array}{l}\text { Immigrants } \\
\text { good economy }\end{array}$} & $-0.976^{\star \star \star}$ & -0.073 & -0.224 & $-0.467^{\star \star}$ & $-0.448^{\star \star}$ \\
\hline & (0.229) & $(0.149)$ & $(0.236)$ & $(0.195)$ & $(0.182)$ \\
\hline \multirow{2}{*}{$\begin{array}{l}\text { Immigrants } \\
\text { bad culture }\end{array}$} & 0.162 & 0.192 & -0.172 & $0.449^{\star}$ & 0.258 \\
\hline & $(0.285)$ & $(0.205)$ & $(0.370)$ & $(0.234)$ & $(0.213)$ \\
\hline \multirow{2}{*}{$\begin{array}{l}\text { Immigrants } \\
\text { bad crime }\end{array}$} & 0.046 & $-0.460^{\star}$ & -0.445 & 0.278 & 0.065 \\
\hline & $(0.300)$ & $(0.253)$ & $(0.442)$ & $(0.245)$ & (0.248) \\
\hline \multirow[t]{2}{*}{ Populism } & $2.786^{\star \star \star}$ & $4.047^{\star \star \star}$ & $2.058^{\star \star \star}$ & $3.072^{\star \star \star}$ & $2.907^{\star \star \star}$ \\
\hline & $(0.722)$ & $(0.479)$ & $(0.762)$ & $(0.617)$ & $(0.576)$ \\
\hline \multirow[t]{2}{*}{ Nativism } & $0.847^{\star \star}$ & $0.748^{\star \star \star}$ & 0.516 & 0.425 & 0.068 \\
\hline & $(0.405)$ & (0.283) & $(0.417)$ & $(0.353)$ & $(0.337)$ \\
\hline \multirow[t]{2}{*}{ Authoritarianism } & -0.730 & $-2.097^{\star \star \star}$ & $-4.978^{\star \star \star}$ & -0.077 & $-2.377^{\star \star \star}$ \\
\hline & $(0.591)$ & $(0.419)$ & $(0.623)$ & (0.618) & $(0.467)$ \\
\hline \multirow[t]{2}{*}{ Left-right } & $-0.375^{\star \star \star}$ & $-0.705^{\star \star \star}$ & $-0.905^{\star \star \star}$ & $-0.315^{\star \star \star}$ & $-0.287^{\star \star \star}$ \\
\hline & $(0.064)$ & $(0.060)$ & $(0.072)$ & $(0.053)$ & $(0.045)$ \\
\hline \multirow[t]{2}{*}{ Constant } & $1.241^{\star \star}$ & $2.332^{\star \star \star}$ & $3.653^{\star \star \star}$ & $-2.387^{\star \star \star}$ & 0.337 \\
\hline & $(0.518)$ & (0.399) & $(0.491)$ & $(0.478)$ & $(0.391)$ \\
\hline Observations & $3,438.000$ & $3,438.000$ & $3,438.000$ & $3,438.000$ & $3,438.000$ \\
\hline
\end{tabular}

Note: Robust standard errors in parentheses.

${ }^{\star \star *} \mathrm{p}<0.01,{ }^{\star \star} \mathrm{p}<0.05,{ }^{*} \mathrm{p}<0.1$, Pseudo R-squared 0.1672 .

Source: New Zealand Election Study (2017). 
This text is taken from A Populist Exception?: The 2017 New Zealand General Election, edited by Jack Vowles and Jennifer Curtin, published 2020 by ANU Press, The Australian National University, Canberra, Australia.

doi.org/10.22459/PE.2020.05 